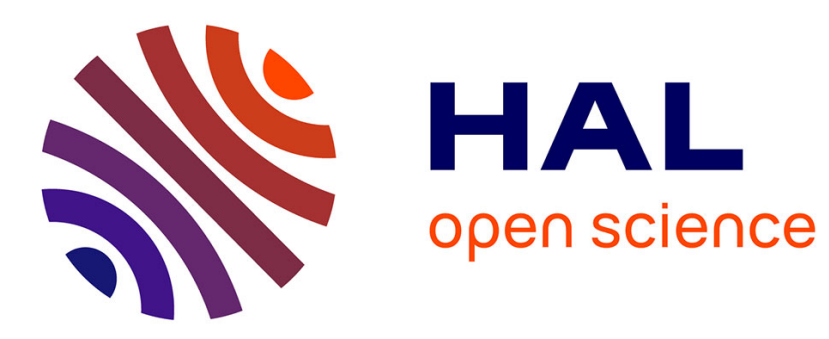

\title{
Cottoning on to Cotton (Gossypium Spp.) in Arabia and Africa during Antiquity
}

Charlène Bouchaud, Alan Clapham, Claire Newton, Gaëlle Tallet, Ursula Thanheiser

\section{- To cite this version:}

Charlène Bouchaud, Alan Clapham, Claire Newton, Gaëlle Tallet, Ursula Thanheiser. Cottoning on to Cotton (Gossypium Spp.) in Arabia and Africa during Antiquity. Mercuri, Anna Maria and D'Andrea, A. Catherine and Fornaciari, Rita and Höhn, Alexa. Plants and People in the African Past: Progress in African Archaeobotany, Springer International Publishing, pp.380-426, 2018, 978-3-319-89839-1. 10.1007/978-3-319-89839-1_18 . hal-02303845

\section{HAL Id: hal-02303845 \\ https://hal.science/hal-02303845}

Submitted on 18 Dec 2019

HAL is a multi-disciplinary open access archive for the deposit and dissemination of scientific research documents, whether they are published or not. The documents may come from teaching and research institutions in France or abroad, or from public or private research centers.
L'archive ouverte pluridisciplinaire $\mathbf{H A L}$, est destinée au dépôt et à la diffusion de documents scientifiques de niveau recherche, publiés ou non, émanant des établissements d'enseignement et de recherche français ou étrangers, des laboratoires publics ou privés. 


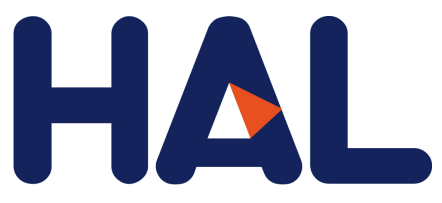

archives-ouvertes

\section{Cottoning on to Cotton (Gossypium Spp.) in Arabia and Africa during Antiquity}

Charlène Bouchaud, Alan Clapham, Claire Newton, Gaëlle Tallet, Ursula

Thanheiser

\section{- To cite this version:}

Charlène Bouchaud, Alan Clapham, Claire Newton, Gaëlle Tallet, Ursula Thanheiser. Cottoning on to Cotton (Gossypium Spp.) in Arabia and Africa during Antiquity. Mercuri, Anna Maria and D'Andrea, A. Catherine and Fornaciari, Rita and Höhn, Alexa. Plants and People in the African Past: Progress in African Archaeobotany, Springer International Publishing, pp.380-426, 2018, 978-3-319-89839-1. 10.1007/978-3-319-89839-1_18. hal-02303845

\section{HAL Id: hal-02303845 \\ https://hal.archives-ouvertes.fr/hal-02303845}

Submitted on 18 Dec 2019

HAL is a multi-disciplinary open access archive for the deposit and dissemination of scientific research documents, whether they are published or not. The documents may come from teaching and research institutions in France or abroad, or from public or private research centers.
L'archive ouverte pluridisciplinaire HAL, est destinée au dépôt et à la diffusion de documents scientifiques de niveau recherche, publiés ou non, émanant des établissements d'enseignement et de recherche français ou étrangers, des laboratoires publics ou privés. 


\section{Cottoning on to Cotton (Gossypium spp.) in Arabia and Africa During Antiquity}

Charlène Bouchaud ${ }^{1}$, Alan Clapham ${ }^{2}$, Claire Newton ${ }^{3}$, Gaëlle Tallet ${ }^{4}$, and Ursula Thanheiser ${ }^{5}$

${ }^{1}$ AASPE-UMR 7209, CNRS-MNHN, Universités Paris-Sorbonne, Paris, France charlene.bouchaud@mnhn.fr

${ }^{2}$ Ely, Cambridgeshire, UK

a.j.clapham@hotmail.co.uk

${ }^{3}$ Laboratoire D'Archéologie et de Patrimoine, Université Du Québec à Rimouski, Rimouski, Canada

clairennewton@gmail.com

${ }^{4}$ CRIHAM-EA 4270, University of Limoges, Limoges, France gaelle.tallet@protonmail.com

5 Vienna Institute for Archaeological Science, University of Vienna, Vienna, Austria ursula.thanheiser@univie.ac.at

\section{Cette version correspond aux épreuves non corrigées. This version corresponds to the uncorrected proofs.}




\section{Metadata of the chapter that will be visualized in SpringerLink}

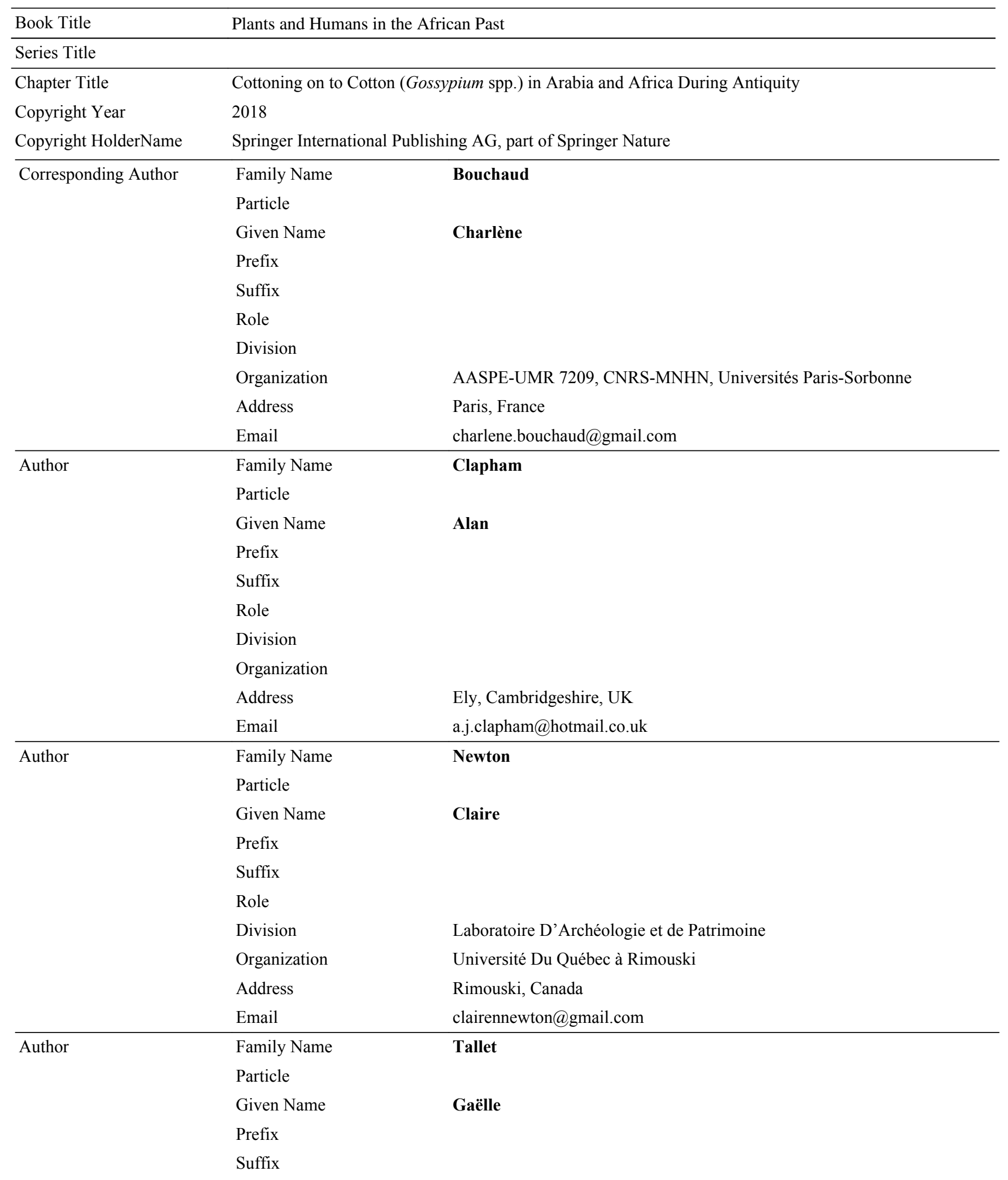




\begin{tabular}{|c|c|c|}
\hline & Role & \\
\hline & Division & \\
\hline & Organization & CRIHAM-EA 4270, University of Limoges \\
\hline & Address & Limoges, France \\
\hline & Email & gaelle.tallet@gmail.com \\
\hline Author & Family Name & Thanheiser \\
\hline & Particle & \\
\hline & Given Name & Ursula \\
\hline & Prefix & \\
\hline & Suffix & \\
\hline & Role & \\
\hline & Division & \\
\hline & Organization & Vienna Institute for Archaeological Science, University of Vienna \\
\hline & Address & Vienna, Austria \\
\hline & Email & ursula.thanheiser@univie.ac.at \\
\hline Abstract & $\begin{array}{l}\text { The occurrence } \\
\text { the emergence } \\
\text { centuries AD, } \\
\text { the two Old W } \\
\text { valley and trad } \\
\text { which very littl } \\
\text { archaeobotanic } \\
\text { attention to sev } \\
\text { (Kellis, Amhei } \\
\text { document how } \\
\text { hypotheses reg } \\
\text { cotton in differ } \\
\text { cotton cultivati } \\
\text { sorghum (Sorg } \\
\text { in north-wester } \\
\text { scaling up durit } \\
\text { Cotton in Nubi } \\
\text { herbaceum, wh } \\
\text { that the increas } \\
\text { the emergence }\end{array}$ & $\begin{array}{l}\text { exts and in the archaeological record (seeds, fibres and textiles) demonstrate } \\
\text { ction centres in north-eastern Africa and western Arabia during the } 1^{\text {st_-4 }}{ }^{\text {th }} \\
\text { rent with an increase of cotton trade. These finds could correspond to any of } \\
\text { otton species: Gossypium arboreum L., probably domesticated in the Indus } \\
\text { millennium BC, or Gossypium herbaceum L., an African species about } \\
\text { side its presence in Nubia during Antiquity. Our paper reviews the } \\
\text { extual data from north-eastern Africa and western Arabia, with specific } \\
\text { ed in Central Sudan (Muweis), Lower Nubia (Qasr Ibrim), western Egypt } \\
\text { vestern Arabia (Madâ' in Sâlih/Hegra). The intention of this review is to a) } \\
\text { ion was integrated into agrarian and trade economies and b) examine current } \\
\text { hronic distribution of the two species. The results highlight the importance of } \\
\text { s from the } 1^{\text {st_-2 }} \text { nd centuries AD. In Central Sudan, Nubia and Dakhlah oasis, } \\
\text { ve appeared together with other new tropical/sub-tropical crops, such as } \\
\text { nd pearl millet (Pennisetum glaucum subsp. glaucum). This was not the case } \\
\text { ms that cotton production occurred at first as small-scale experiments before } \\
\text { Iry AD, in conjunction with the spread of the water-wheel in the Nile valley. } \\
\text { in other neighbouring areas, probably belonged to the African species } G \text {. } \\
\text { ikelihood domesticated in southern regions, perhaps Ethiopia. We suggest } \\
\text { across the Indian Ocean during Antiquity created a favourable context for } \\
\text { Iction and its relative expansion before the Islamic period. }\end{array}$ \\
\hline $\begin{array}{l}\text { Keywords } \\
\text { (separated by '-') }\end{array}$ & Antiquity - Ara & Gossypium herbaceum/arboreum - Northeastern africa \\
\hline
\end{tabular}




\title{
Cottoning on to Cotton (Gossypium spp.) in Arabia and Africa During Antiquity
}

\author{
Charlène Bouchaud ${ }^{1(\bowtie)}$, Alan Clapham ${ }^{2}$, Claire Newton $^{3}$, \\ Gaëlle Tallet ${ }^{4}$, and Ursula Thanheiser ${ }^{5}$ \\ 1 AASPE-UMR 7209, CNRS-MNHN, Universités Paris-Sorbonne, Paris, France \\ charlene.bouchaud@gmail.com \\ ${ }^{2}$ Ely, Cambridgeshire, UK \\ a.j.clapham@hotmail.co.uk \\ 3 Laboratoire D'Archéologie et de Patrimoine, Université Du Québec à \\ Rimouski, Rimouski, Canada \\ clairennewton@gmail.com \\ ${ }^{4}$ CRIHAM-EA 4270, University of Limoges, Limoges, France \\ gaelle.tallet@gmail.com \\ 5 Vienna Institute for Archaeological Science, University of Vienna, Vienna, \\ Austria \\ ursula.thanheiser@univie.ac.at
}

\begin{abstract}
The occurrences of cotton in texts and in the archaeological record (seeds, fibres and textiles) demonstrate the emergence of cotton production centres in north-eastern Africa and western Arabia during the $1^{\text {st }}-4^{\text {th }}$ centuries $\mathrm{AD}$, which is concurrent with an increase of cotton trade. These finds could correspond to any of the two Old World domestic cotton species: Gossypium arboreum L., probably domesticated in the Indus valley and traded since the $3^{\text {rd }}$ millennium BC, or Gossypium herbaceum L., an African species about which very little is known, beside its presence in Nubia during Antiquity. Our paper reviews the archaeobotanical, textile and textual data from north-eastern Africa and western Arabia, with specific attention to several sites located in Central Sudan (Muweis), Lower Nubia (Qasr Ibrim), western Egypt (Kellis, Amheida) and north-western Arabia (Madâ'in Sâlih/Hegra). The intention of this review is to a) document how cotton production was integrated into agrarian and trade economies and b) examine current hypotheses regarding the diachronic distribution of the two species. The results highlight the importance of cotton in different agrosystems from the $1^{\text {st }}-2^{\text {nd }}$ centuries AD. In Central Sudan, Nubia and Dakhlah oasis, cotton cultivation seems to have appeared together with other new tropical/sub-tropical crops, such as sorghum (Sorghum bicolor) and pearl millet (Pennisetum glaucum subsp. glaucum). This was not the case in north-western Arabia. It seems that cotton production occurred at first as small-scale experiments before scaling up during the $3^{\text {rd }}$ century $\mathrm{AD}$, in conjunction with the spread of the water-wheel in the Nile valley. Cotton in Nubia, and possibly in other neighbouring areas, probably belonged to the African species $G$. herbaceum, which was in all likelihood domesticated in southern
\end{abstract}


regions, perhaps Ethiopia. We suggest that the increase of exchanges across the Indian Ocean during Antiquity created a favourable context for the emergence of cotton production and its relative expansion before the Islamic period.

Keywords: Antiquity $\cdot$ Arabia $\cdot$ Cotton $\cdot$ Gossypium herbaceum/arboreum Northeastern africa

\section{Introduction}

Two main hypotheses concerning cotton distribution in the Old World prevail to date. The first is that commercial expansion of cotton production and textile in south-west Asia, northern Africa and the Mediterranean basin was concomitant with the Arab conquest. The second suggests that until the $19^{\text {th }}$ century and the spread of the American cotton, cotton textiles mainly came from India where they had been manufactured and transformed for many years (Mazzaoui 1981; Watson 1983; Wild 1997; Lombard 2002; Bulliet 2009). Recent archaeological discoveries of cotton seeds and textile are significantly modifying our understanding, demonstrating the existence of cotton production centres in north-western Arabia and north-eastern Africa already at the turn of the $1^{\text {st }}-3^{\text {rd }}$ centuries AD (Clapham and Rowley-Conwy 2009; Bouchaud et al. 2011; Tallet et al. 2012; Fuller 2014). Some of these data include cotton plants domesticated in Africa (Palmer et al. 2012). The present collaborative study is based on archaeobotanical and textual corpuses, and to a lesser extent, on textile remains. We aim to review the diachronic distribution of cotton in western Arabia and north-eastern Africa during the first centuries AD. In addition we investigate the impact of cotton production on agrarian dynamics by examining different sites located in Central Sudan (Muweis), Lower Nubia (Qasr Ibrim), western Egypt (Kellis, Amheida) and north-western Arabia (Madâ'in Sâlih).

The paper begins with a presentation of biological aspects of cotton and presents the methodological framework of the study, followed by a description of archaeobotanical results from five archaeological sites, including Muweis (Central Sudan), Qasr Ibrim (Lower Nubia), Kellis and Amheida (western Egypt) and Madâ'in Sâlih/Hegra (north-western Arabia). We then review general results on seed, textile and text discoveries of cotton in western Asia and north-eastern Africa. These data will allow us to address several issues concerning the diffusion of cotton products and its cultivation in these regions, including management practices, the significance of plant macro-remains of cotton in archaeological contexts, the biological origin of cotton in Africa and economic and social aspects associated with the spread of cotton cultivation.

\section{Botanical and Genetic Background}

Cotton belongs to the Malvaceae family and the genus Gossypium, which comprises approximately 45 herbaceous and woody perennial wild species growing at tropical and sub-tropical latitudes (Wendel and Cronn 2003; Page et al. 2013). The fruit of cotton is a rigid capsule that opens at maturity in form of a boll composed of oleaginous 
seeds surrounded by fine fibres used for textile production. The bolls are divided into three to five loculi, each containing six to nine seeds. Two kinds of epidermal hairs (trichome) cover the seed coat. The longest constitute the lint that can be easily pulled off at maturity to be spun and weaved. The shortest trichomes or "fuzz" (2-7 mm long) are more difficult to remove and are used today as cotton wool (Reis et al. 2006:47).

Cotton relies for growth and maturation on hot and humid short days. Today, it is grown between latitudes of $37^{\circ}$ north ( $45^{\circ}$ north in China) and $30^{\circ}$ south in temperate, subtropical and tropical regions. The cotton plant is a perennial small tree but has been progressively domesticated and selected to be grown as a pseudo-annual shrub. Present-day varieties grow $25 \mathrm{~cm}$ to over $2 \mathrm{~m}$ high, depending on how they are cultivated. Cotton still grows as perennial bushes only in a few regions, including South America (Peru, Brazil), Africa (Ethiopia), Central Asia and Northern India. The basic conditions required for its successful production include a long frost-free period, a temperature range of $18^{\circ}-32^{\circ} \mathrm{C}$ and a minimum of $500 \mathrm{~mm}$ of water over the long growing cycle, which lasts 125-225 days depending on varieties and local climate. Whereas winter crops, such as barley and wheat, are sown in the autumn with lengthening days after the winter solstice leading to a spring harvest, cotton requires shortening day lengths after the mid-summer solstice to stimulate flowering. However, most modern cultivars are day-length neutral. In the northern hemisphere, sowing occurs in March to April and harvest lasts from the end of July to December-January. Cotton exhibits a certain degree of tolerance to salt and drought (Stephens 1976; Smith and Cothren 1999; Chaudhry and Guitchounts 2003; Reis et al. 2006:49).

Four different species of cotton were independently domesticated, two of the tetraploid AD-group in the New world and two others of the diploid A-group in the Old World (Paterson et al. 2012). Of the two species from America, Gossypium hirsutum L. was domesticated in Central America and G. barbadense L. in Peru (Smith and Stephens 1971; Stephens 1975; Dillehay et al. 2007). Gossypium hirsutum is the most frequently cultivated cotton plant in the world today and has often replaced the other species. The two Old World species, G. herbaceum L. and G. arboreum L., are more resistant to water stress and pests and are adapted to shallow and sandy soils, but have a shorter staple length and are now cultivated less than the American species. The staple length of cotton fibres varies from 10 to $60 \mathrm{~mm}$ according to the four different species but the fibres of $G$. arboreum and $G$. herbaceum do not exceed $20 \mathrm{~mm}$ on average (Benedict et al. 1999). The Old World cottons are still exploited by small farmers in West Africa, western Egypt, India, Bangladesh, Pakistan and Iran (Brubaker et al. 1999; Wendel et al. 1999; Boulos 2000:111; Eyhorn et al. 2005).

There are still important issues concerning the domestication processes of G. arboreum and $G$. herbaceum. Genetic and morphological arguments indicate that $G$. herbaceum was derived from its wild ancestor G. herbaceum var. africanum (G. Watt) Vollesen, which grows naturally in southern Africa today. Gossypium arboreum has a primitive perennial form $G$. arboreum race 'indicum' growing in western India, but its wild ancestor is unknown (Stanton et al. 1994; Kulkarni et al. 2009). Archaeological evidence raises contrasting and supplementary views. First, the extant distribution of G. herbaceum var. africanum is much more southern than the most ancient and reliable 
archaeological evidence of the use of cotton, known to date to the $1^{\text {st }}$ century $\mathrm{BC}-1^{\text {st }}$ century AD in Lower Nubia (Clapham and Rowley-Conwy 2009). Secondly, the discovery of textiles and seeds dating to the $6^{\text {th }}-4^{\text {th }}$ millennium BC point to a possible centre of domestication of G. arboreum in Pakistan (Moulhérat et al. 2002).

\section{Nature of the Available Data}

This review is based on archaeological plant macro-remains, textiles, and epigraphic evidence. The possibility of recovering each type of evidence is the result of several complex taphonomic, processing (chaîne opératoire) and preservation processes. As a result the information presented may not be consistent or directly comparable to each class of evidence.

\section{Production and Preservation of the Archaeological and Textual Data}

The harvest of cotton bolls is traditionally done by hand, leaving behind most of the bracts that surround the bolls as well as stems and leaves, which can then be harvested separately and used as fuel (Abasaeed 1992; Gomes et al. 1997) or fodder (Suttie 2004, 168). To release the fibres from the seeds, the ginning process was carried out until modern times by hand or by rolling a cylinder or wooden stick on the bolls laid on a smooth flat stone. Within the domestic sphere, women generally undertook this task (Nicholson 1960:14; Leroi-Gourhan 1971:247). The carding process, using a comb or a bow, allows the fibres to be fluffed. This last step is however not compulsory. Until recently in Sudan, the fibre was spun immediately after gently removing the lint from the seed in order to keep the fibres in their original order, lying as parallel to each other as possible, so as to avoid the soft fluffs to be mixed up and to make the fibres more durable, soft and warm (Crowfoot 1924; Nicholson 1960:14). In Egypt and Nubia, modern and archaeological examples show the occurrence of different spinning methods with a hand-held or suspended spindle. The spindle whorls are made of unfired clay, stone, wood, bone, ceramic or potsherds, and placed at the top of the spindle, often secured by the insertion of an iron hook between the shaft and the whorl's central perforation (Crowfoot 1931; Yvanez 2016). After spinning, cotton threads are then ready to be weaved using a horizontal loom or a warp-weighted loom (Leroi-Gourhan 1971).

The discovery of cotton seeds, spun or unspun fibres and textiles in archaeological contexts is thus a direct link to specific processing steps of the chaine opératoire (Leroi-Gorhan 1971) as well as evidence of household and commercial activities (through the transport of raw or manufactured cotton). However, their preservation heavily depends on taphonomic processes, as organic materials such as seeds, fibres, papyri, wooden books, etc. are generally destroyed through biological decay. Thankfully, some regions of north-eastern Africa and the Arabian Peninsula offer a hyper-arid climate and/or contexts without much oxygen, such as tombs, which permit a partial 
conservation of organic remains. In other, more "humid" areas, only charred material tends to be preserved. This study also takes into consideration textual sources that are mostly Greek texts found in Egypt in the form of ostraca, papyri and wooden books. In Sudan and Nubia, documents written in the Meroitic script could possibly reveal new data, but their translation still remains difficult and requires further study and analysis (Rilly 2007).

\section{Interpretive Potential}

Plant remains, textiles and texts can provide details on the location of production centres, distribution and trade activities, original uses, and the taxonomic status of cotton.

Textiles are often found in tombs of high-ranking individuals, providing selective information on elite production, and a few, more recently discovered specimens have arisen from household contexts. Textiles were essential commodities and often the subject of exchange and trade. As such, their presence in a context is not necessarily directly linked to their place of production. On the contrary, spinning and weaving techniques are strongly embedded in social identity and can potentially be good spatiotemporal markers (Wild 1997). The yarn itself for example, the direction of the fibre twist, which depends on the rotation direction of the spindle, varies from one region to another, based on long-lived cultural traditions (Barber 1993:39-50; Wilkinson 2014:249-50). The substantial textile corpus from the Nile valley shows that S-spun yarns - created by an anti-clockwise rotation of the spindle - are dominant in both Egypt and Nubia (Crowfoot 1931; Wild 1997). This specificity seems relates to the pharaonic tradition of flax-spinning, for this fibre naturally curls to the left $(S)$ when dampened (Barber 1993). Z-spun threads-clockwise rotation of the spindle-are however dominant in India and Central Asia (Wild and Wild 2014a; Wilkinson 2014). The spinning tradition of the ancient Arabian Peninsula is not well defined to date. When they are sufficiently well preserved, the type of fabrics, weaves, patterns, and colours are all very good indicators of the origin of textiles.

Charred and desiccated non-manufactured elements, such asbolls, isolated fibres, wads of raw cotton, empty capsule (i.e., pericarp, whole and broken seeds) likely lie within agricultural production centres as they result from the cleaning of the cotton plant prior to any use of the fibres. However, we need to consider that the harvests of different places (fields, owners, villages) could have been centralised in domestic or in specialised (urban) workshops for further processing. In this way, remains of cotton seeds would indicate that cotton likely grew in the neighbouring villages, but perhaps not around the town itself (see section IX.B.). Raw fibres with seeds still attached could also circulate by long-distance trade (see section IV.E.). Identifying local production only from carpological clues such as seeds thus remains problematic, except when other harvesting by-products are also found, such as empty capsules (pericarps) (Clapham and Rowley-Conwy 2009). Whether it be seeds or textiles, the strongest element indicating local production is the statistical domination of cotton in both the 
archaeobotanical samples and textile assemblage of the site under study. Cotton wood, which would be relevant to attest local production, has never been identified to date (Bouchaud et al. 2011). Finally, the analysis of textile implements, especially spindle whorls, could also benefit our understanding of fibre and thread production. The weight of the whorl is particularly interesting, as different fibres require different force to be effectively spun: light to medium weight (10-30 g) for short fibres such as cotton and medium length wool, and heavier tools for long length wool and linen (see Barber 1993; Yvanez 2016:163).

Seeds and textiles provide the same taxonomic signal at the genus level (Gossypium sp.). In other words, there is no possibility to distinguish $G$. herbaceum from $G$. arboreum on a morphological basis. Several identification proposals have already been made, notably based on the thread diameter (Chowdhury and Buth 1971; Coombs et al. 2002), but the results are ambiguous and should be reassessed through new morphometric studies. On well-preserved material, archaeogenomic analyses also have provided interesting perspectives and show promise (Palmer et al. 2012).

The majority of texts dealing with cotton are private letters mentioning garments or threads, official agricultural surveys citing cotton plants, military accounts and orders of delivery, as well as private book accounts and receipts listing quantities of cotton. In the Egyptian written corpus, cotton is generally designated by the Greek term

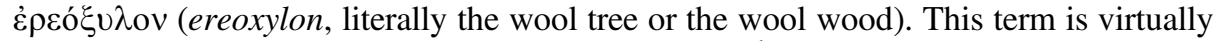
absent from the other Greek sources. During the $4^{\text {th }}$ century BC, Theophrastus for

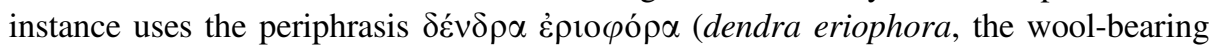
tree) to designate the cotton tree in Bahrein ${ }^{1}$ (Historia Plantarum 4.7.7). The anonymous author of the Periplus Maris Erythraei, a Greek handbook compiled by an Alexandrian sailor as a guide to merchants engaged in long-distance trade in the Red Sea and Indian Ocean, uses a transcription of the Sanskrit term kârpâsa into Greek $\kappa \alpha ́ \rho \pi \alpha \sigma o$ (karpaso), by which he specifically designates the material Indian clothes are made of (Casson 1989). Several Latin texts refer to gossypinus and xylon, showing that the plant was known, at least to initiated persons, throughout the Mediterranean basin. The texts give information about the location of agricultural and craft production centres, the various uses and shape of the plant, as well as trade. Despite their scarcity and their focus on Indian and Egyptian cultures, literary accounts provide detailed historical descriptions that usefully complete archaeobotanical or textile studies.

\section{Archaeobotanical Finds in Nubia, Egypt and Saudi Arabia}

At least fifteen archaeological settlements located in north-eastern Africa and western Arabia have produced cotton archaeobotanical remains more or less securely dated to the Antique and Late Antique periods (Fig. 1, Table 1). We exclude from this list the

\footnotetext{
${ }^{1}$ For a complete view of cotton production in Bahrein during Achaemenid period, see (Bouchaud et al. 2011; Tengberg and Lombard 2001).
} 


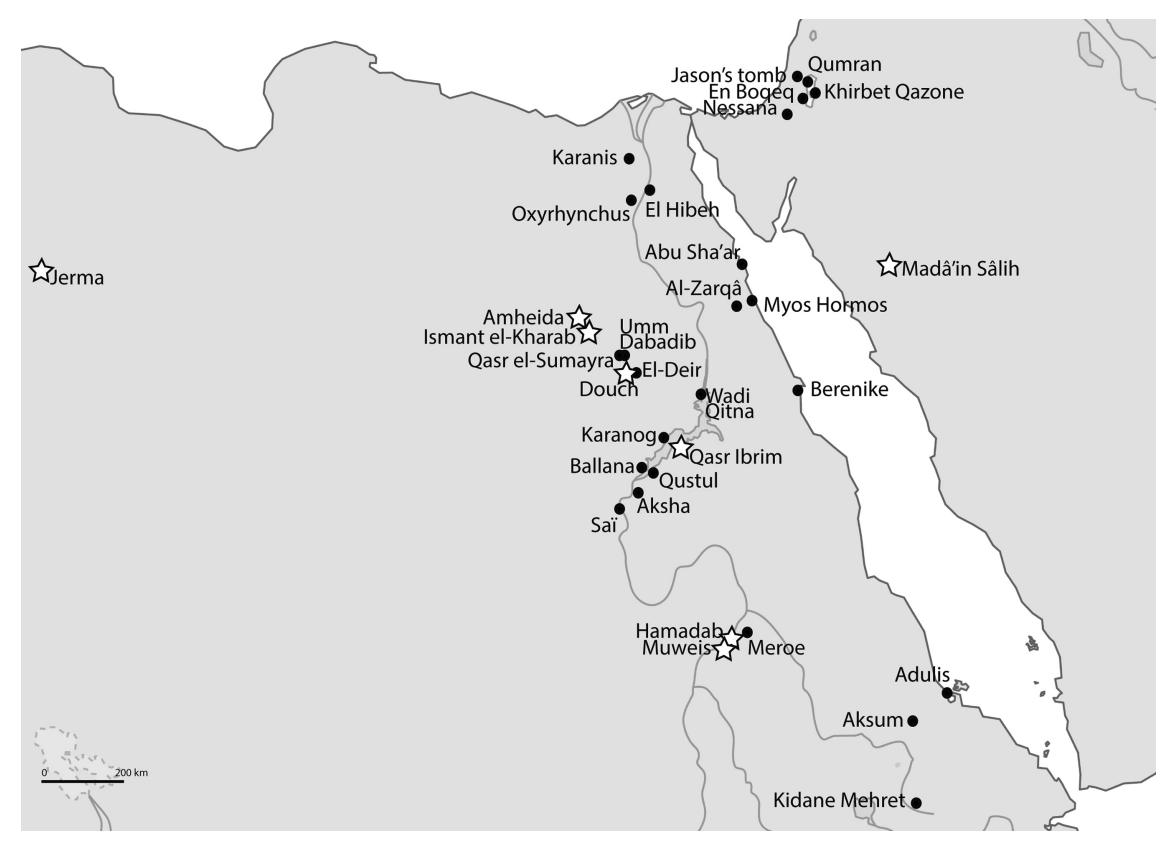

Fig. 1. Mapping the evidence for cotton in Northeastern Africa, Western Arabia and the Near East, 1 st century BC $-7^{\text {th }}$ century AD. For more details, see Table 1 . The names refer to either ancient or modern names. Stars designate the sites for which cotton production is assumed, eitherlocally or in the region.

unique discovery of desiccated cotton seeds at Afyeh (Nubia) insecurely dated to the $3^{\text {rd }}$ millennium BC because of the context of the finds (in goat faeces) and the absence of direct radiocarbon dating (Chowdhury and Buth 1971; see criticisms in Clapham and Rowley-Conwy 2009, 249; Fuller 2015:14). Five of these sites, Qasr Ibrim (Lower Nubia, Egypt), Muweis (Central Sudan), Madâ'in Sâlih (north-western Arabia), Kellis and Amheida (Dakhlah Oasis in the Western Desert of Egypt) and their cotton discoveries are detailed below to consider the representation of cotton items and their potential significance in terms of use and production in various environments. The quantitative description of the cotton finds is based on the occurrence of cotton remains, i.e., the number of samples where the taxon is recognized, and in some cases on the proportion of each type of remain (raw number of remains). For two sites, the occurrence of cotton is compared with that of other economic plants. Qualitative descriptions are used when the quantitative ones are not yet available. A list of other significant cotton finds is also added to these detailed descriptions. 


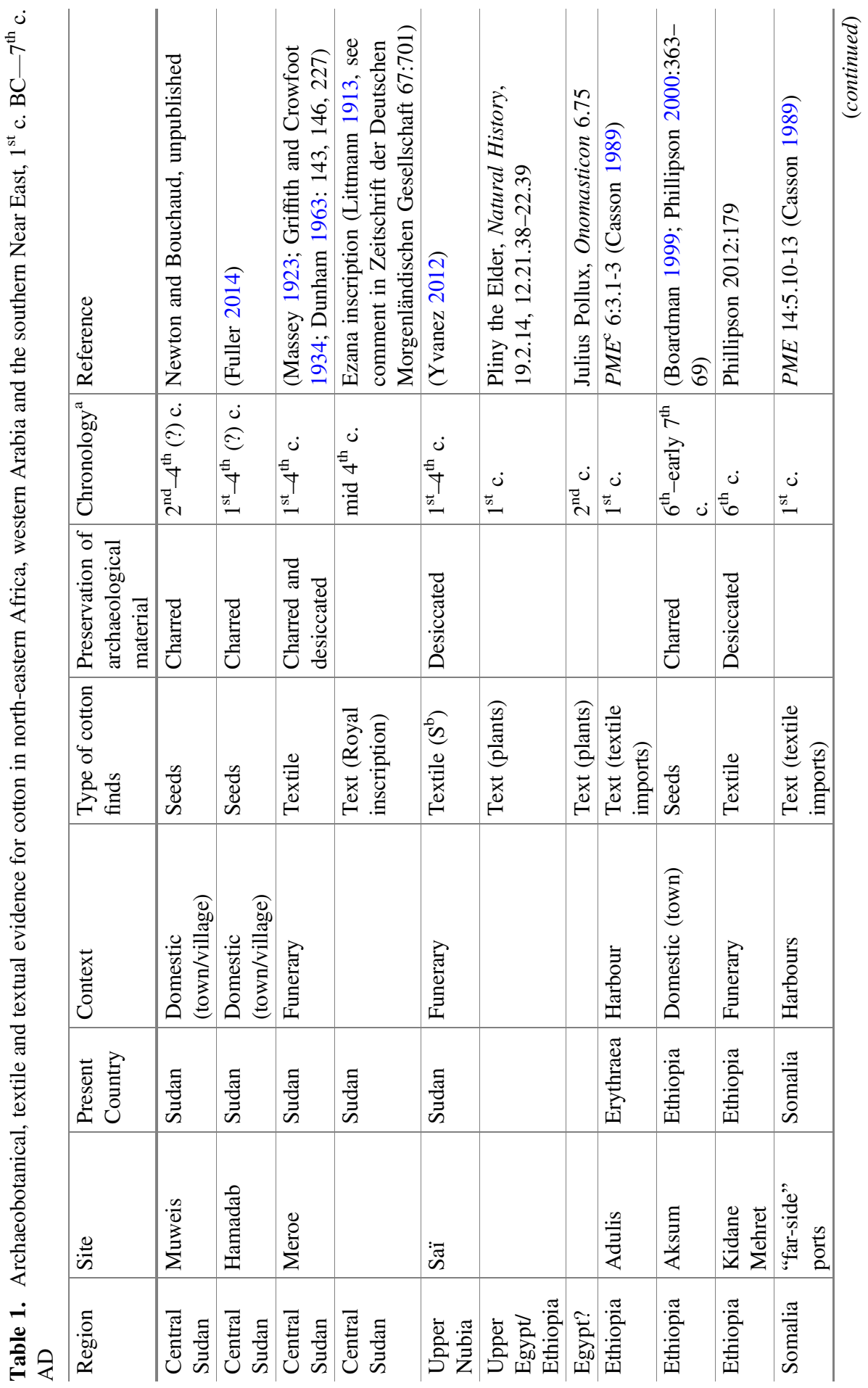




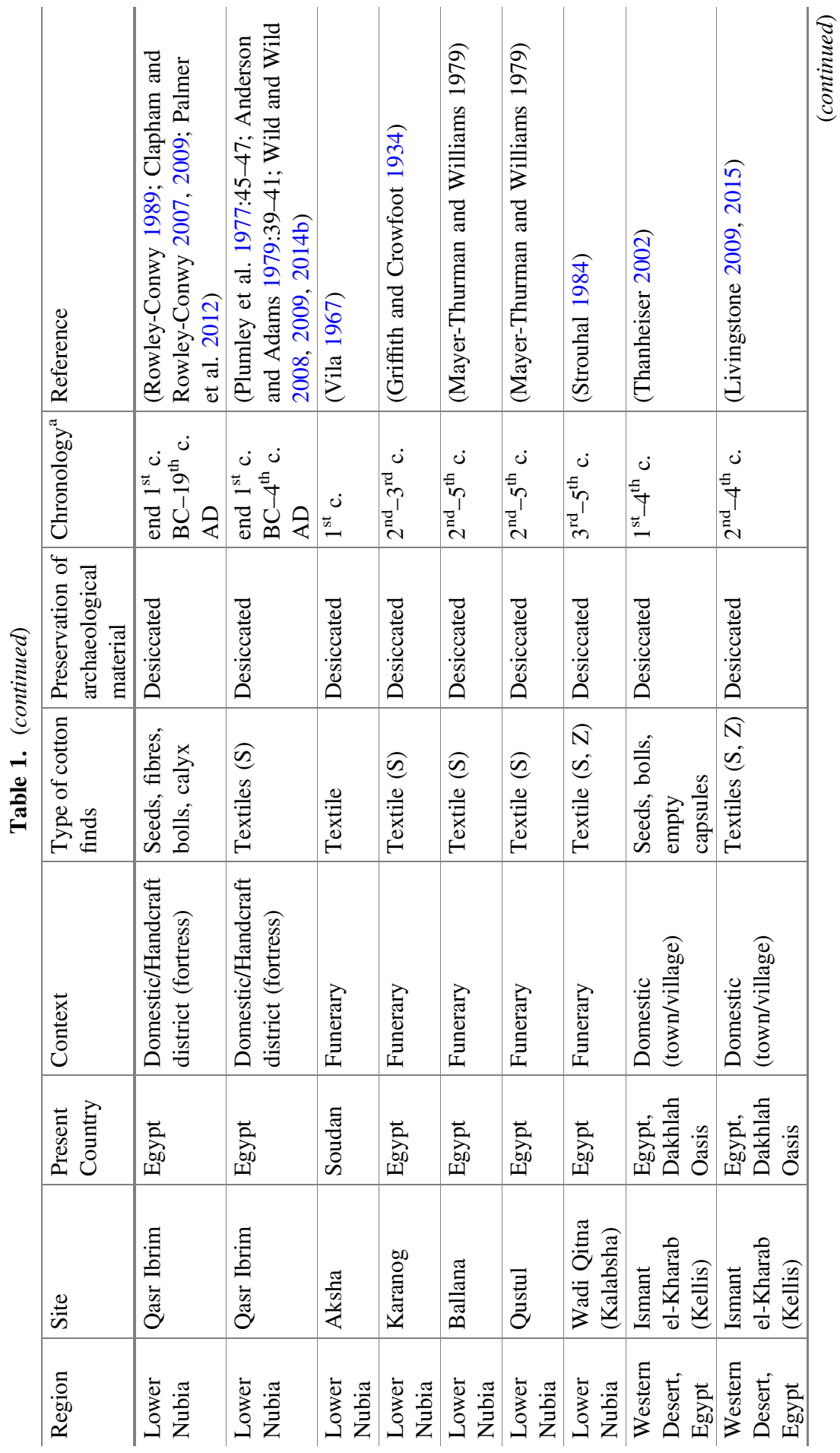




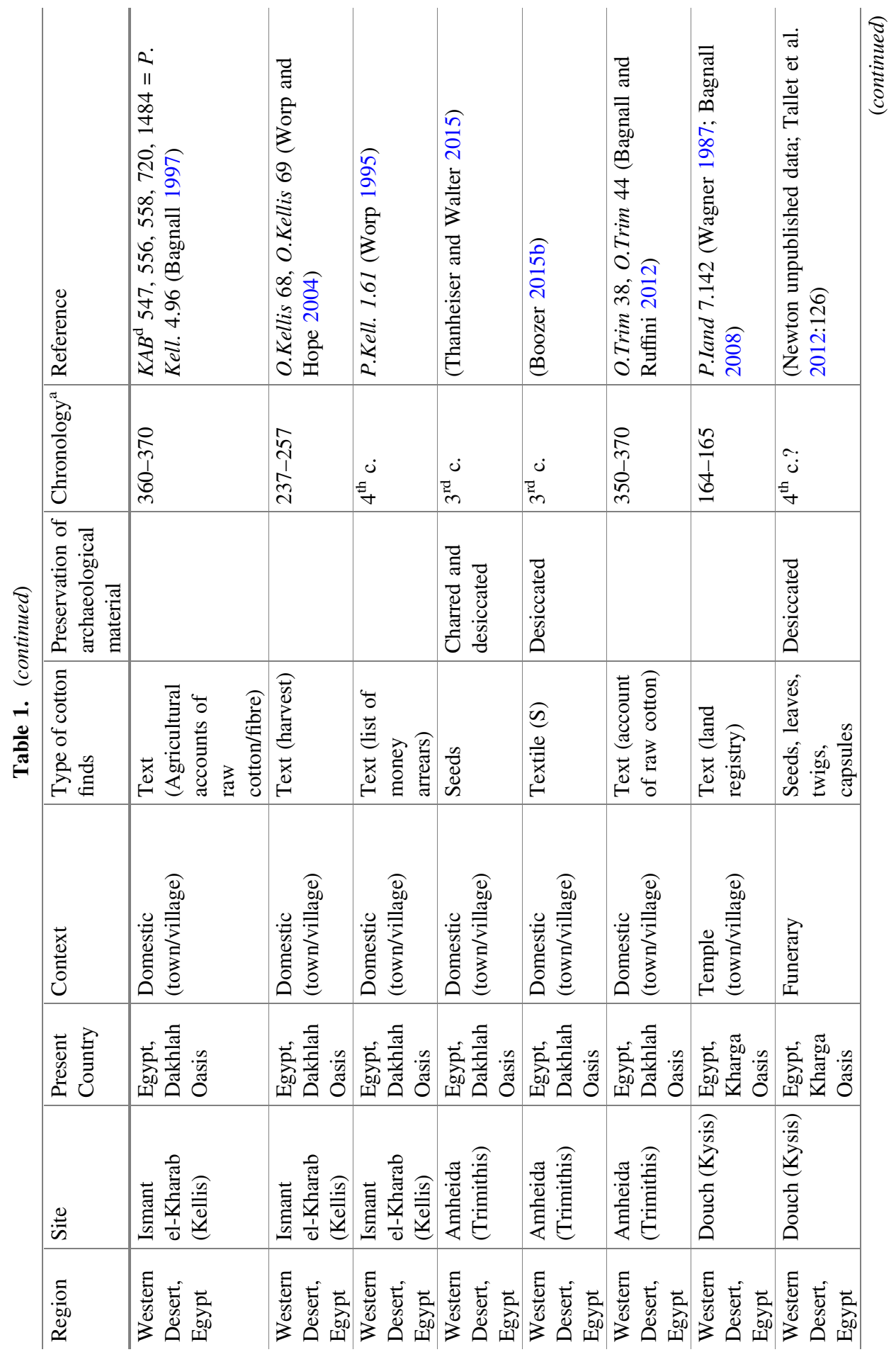




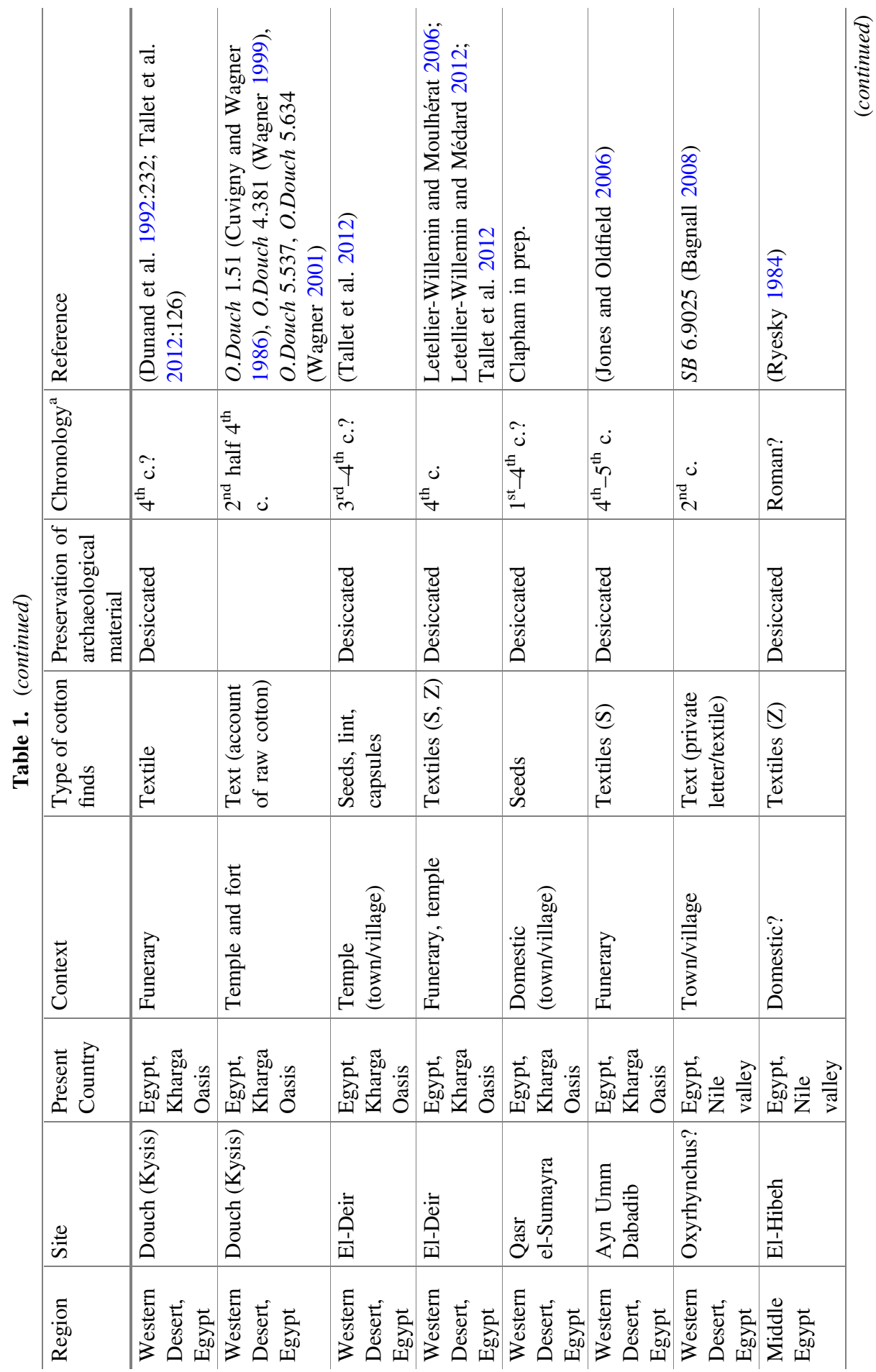




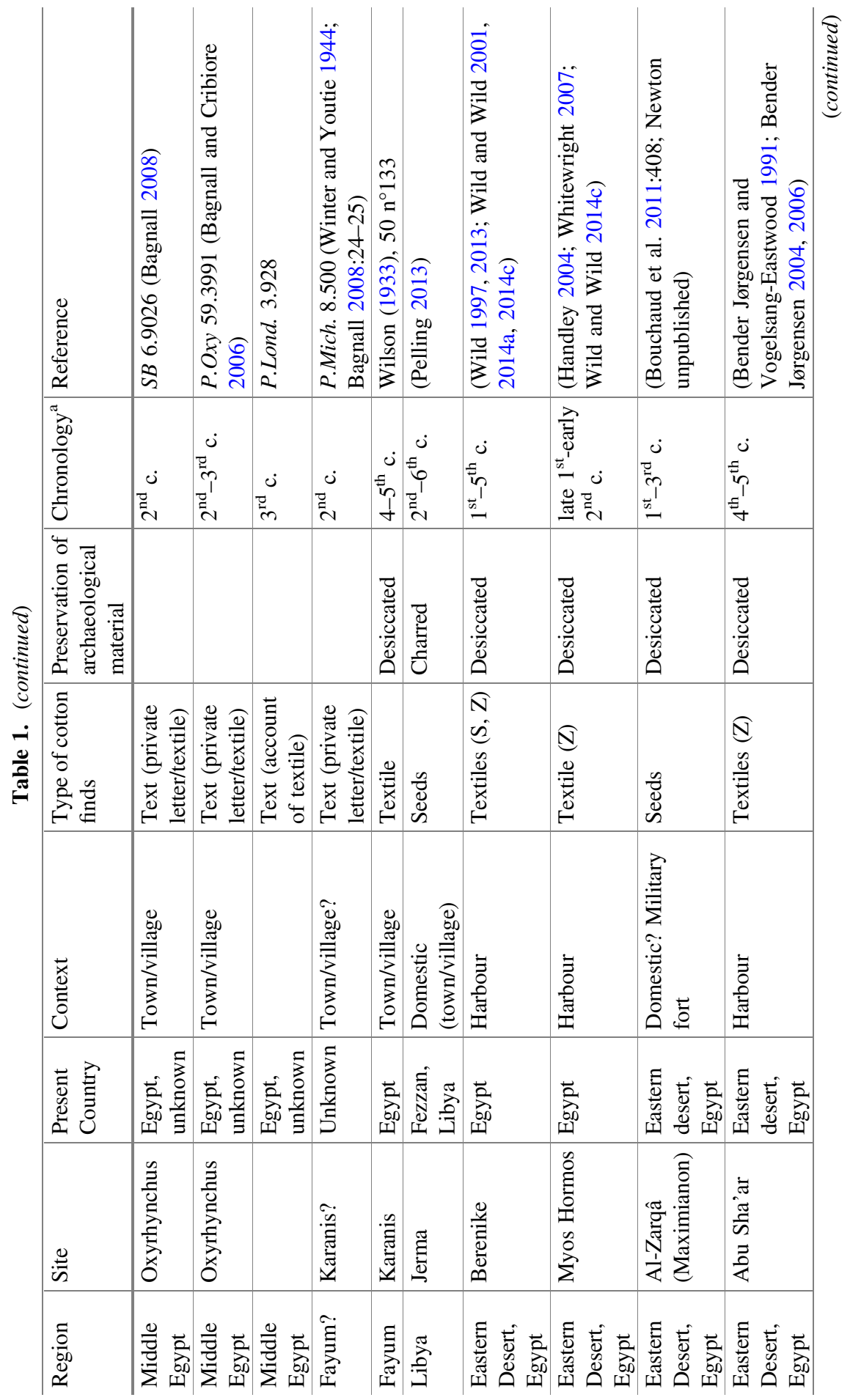




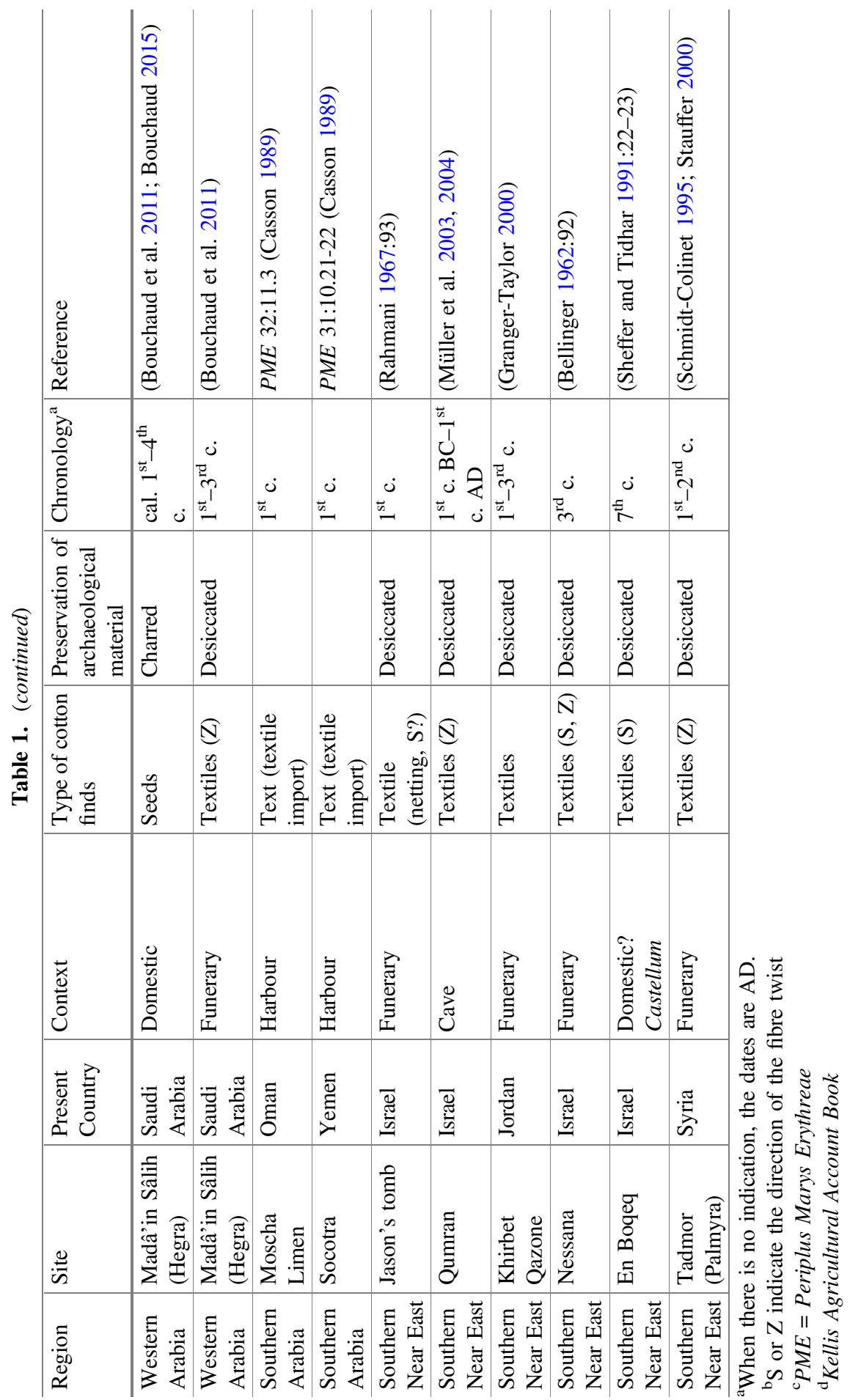




\section{Qasr Ibrim (Lower Nubia)}

Qasr Ibrim, Roman Primis, is located in Lower Nubia about $185 \mathrm{~km}$ south of the first cataract of the Nile. Before the building of the Aswan High Dam and the creation of Lake Nasser, the site was a promontory fort at the top of the eastern flank of the steep-sided Nile valley. It was excavated more or less continuously from 1963 to 2006 (Rose 1996, 2011, 2013). Qasr Ibrim was a major settlement and cult centre within the area controlled by the Napatan Empire during the $1^{\text {st }}$ millennium BC. A Roman garrison occupied it from the end of the 1 st century $\mathrm{BC}$ into the $1^{\text {st }}$ century AD. After the Roman withdrawal in the early first century AD, the Meroitic state established control of Qasr Ibrim. With the collapse of the centralised Meroitic state by the mid- $4^{\text {th }}$ century, local polities developed in Lower Nubia, in which Qasr Ibrim continued to have a major role, and this continued after the conversion of Nubia to Christianity. Eventually Qasr Ibrim became the site of an Ottoman garrison, until it was abandoned in the early $19^{\text {th }}$ century. The fortified and isolated character of the settlement and the presence of religious structures dating to almost all periods suggest a specialised urban character. The occupants may have been associated with the maintenance of state and religious institutions, and thus, in some sense, 'officials' rather than representative of a cross-section of society, the majority of whom would probably have lived in the valley (Rose and Edwards 1998; Edwards 2004; Rose 2011).

The arid environmental conditions have led to the impressive preservation of organic material. The study of the plant macro-remains, mainly desiccated, was undertaken by Peter Rowley-Conwy (Rowley-Conwy 1989; Rowley-Conwy et al. 1999), then by Alan Clapham (Clapham and Rowley-Conwy 2007, 2009). The data so far highlight the changes in crops and agricultural regimes from the Napatan until the abandonment of the site. The earliest crop assemblage (Napatan) is similar to those found farther north in the Nile valley in Pharaonic Egypt, characterised by emmer wheat (Triticum turgidum L. subsp dicoccon (Schrank) Thell), hulled barley (Hordeum vulgare L.), small amounts of foxtail millet (Setaria italica (L.) P. Beauv.) and flax (Linum usitatissimum L.). In the Roman period (25 BC-100 AD), a number of crops make their first appearance, albeit in a small way. These include hard wheat (Triticum turgidum L. subsp. durum (Desf.) Husn.), domesticated sorghum (Sorghum bicolor (L.) Moench subsp. bicolor), pearl millet (Pennisetum glaucum (L.) R. Br. subsp. glaucum), olive (Olea europaea L.), and grape (Vitis vinifera L.).

Cotton appears for the first time as isolated desiccated seeds and desiccated fibres with seeds (Table 2). A cotton thread attached to a heddle leash found dating to the Roman occupation produced a calibrated radiocarbon date of 100 BC-AD 70 (2 sigmas, OxA 14813) and coincides with the short term Roman occupation of the site. Two radiocarbon dates from seeds ranging from $40 \mathrm{BC}$ to $\mathrm{AD} 90$ (2 sigma, OxA14810), 20 BC-AD 30 (2 sigma, OxA14812) may suggest an introduction of cotton cultivation to the site during or slightly before the Roman occupation. From the Meroitic period (AD 100-350) until the $19^{\text {th }}$ century, sorghum dominates the cereal remains, although barley and pearl millet remain significant. Bread wheat (Triticum aestivum L. subsp. aestivum) and lablab (Lablab purpureus (L.) Sweet), a tropical legume crop, are introduced during the post-Meroitic period (350-550 AD) (for more details about the 
Table 2. Types and number of cotton remains from each period of occupation at Qasr Ibrim, Egyptian Nubia (Data from quantified samples only)

\begin{tabular}{l|l|r|l|l|l|r}
\hline Period & Roman & Meroitic & $\begin{array}{l}\text { Post } \\
\text { meroitic }\end{array}$ & Christian & Islamic & Totals \\
\hline Date range & $\begin{array}{l}\text { c25BC- } \\
\text { AD100 }\end{array}$ & $\begin{array}{l}\text { AD100- } \\
350\end{array}$ & $\begin{array}{l}\text { AD350- } \\
550\end{array}$ & $\begin{array}{l}\text { AD550- } \\
1400\end{array}$ & $\begin{array}{l}\text { AD1400- } \\
1812\end{array}$ & \\
\hline Number of samples & $\mathbf{1 3}$ & $\mathbf{3 9}$ & $\mathbf{4 1}$ & $\mathbf{1 7}$ & $\mathbf{2}$ & $\mathbf{1 1 2}$ \\
\hline Remain type & & & & & & \\
\hline Desiccated & & & & & & \\
\hline Complete bolls & 0 & 1 & 0 & 0 & 0 & 1 \\
\hline Fibres with seeds & 4 & 9 & 14 & 1 & 1 & 29 \\
\hline Seed free fibres & 0 & 5 & 7 & 0 & 0 & 12 \\
\hline $\begin{array}{l}\text { Pericarp (=empty } \\
\text { capsules) }\end{array}$ & 0 & 2 & 6 & 0 & 0 & 8 \\
\hline Pericarp fragments & 8 & 75 & 68 & 41 & 2 & 194 \\
\hline Seeds & 67 & 322 & 393 & 10 & 1 & 793 \\
\hline Seed fragments & 707 & $569+$ & 284 & 80 & 19 & $1090+$ \\
\hline Cotyledons & 4 & 32 & 9 & 0 & 0 & \\
\hline Total desiccated & $\mathbf{7 9 0}$ & $\mathbf{1 0 1 6 +}$ & $\mathbf{7 8 1}$ & $\mathbf{1 3 2}$ & $\mathbf{2 3}$ & \\
\hline Charred & & & & & & \\
\hline Seeds & 0 & 8 & 29 & 0 & 0 & 37 \\
\hline Seed fragments & 1 & 131 & 0 & 1 & 0 & 133 \\
\hline Total charred & $\mathbf{1}$ & $\mathbf{1 3 9}$ & $\mathbf{2 9}$ & $\mathbf{1}$ & & \\
\hline
\end{tabular}

archaeobotanical finds, see (Clapham and Rowley-Conwy 2007). Cotton finds are also very well attested during the Meroitic and Post-Meroitic periods.

Cotton plant remains are mainly present in the form of desiccated and charred fragmented and whole seeds (Table 2). Most of them have no long fibres and correspond, at least for the desiccated ones, to a post-ginning phase. We cannot exclude that the charring process has destroyed the original lint. Some of the desiccated cotton seeds have long fibre remains still attached to the seed coat and may indicate a pre-ginning stage. Plant remains, rarely encountered in archaeological contexts, are represented among the desiccated assemblage in the form of complete bolls (including immature bolls), empty capsules (pericarp) and free long fibres (Fig. 2).

In addition to archaeobotanical study, the remarkable preservation of the plant remains has led to their examination through various biomolecular analyses in order to determine the history and origins of certain crops such as sorghum (Rowley-Conwy et al. 1999; Shaw et al. 2001) and six-row barley (Palmer et al. 2009; Smith et al. 2014). Ancient DNA analyses (transposable elements composition) conducted on cotton seeds stratigraphically dated to the $4^{\text {th }}$ century $\mathrm{AD}$ allowed to determine the species G. herbaceum, of African origin (Palmer et al. 2012). 


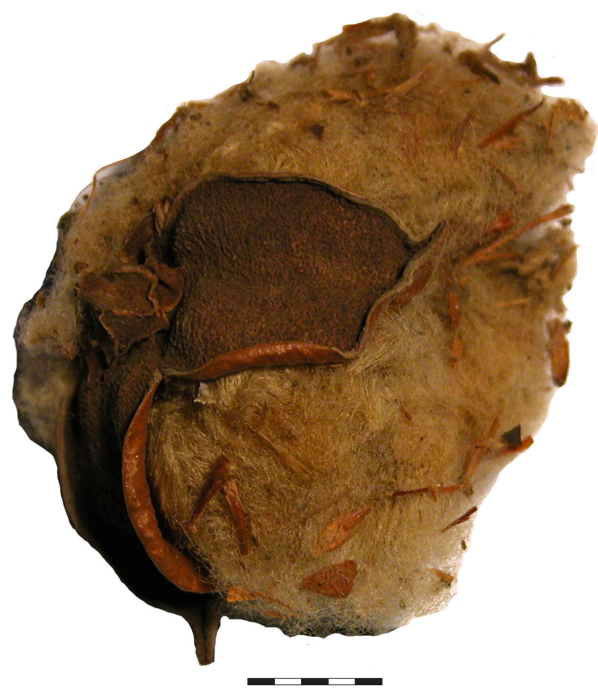

Fig. 2. Desiccated complete boll/capsule of cotton from Qasr Ibrim (Lower Nubia), including perianth remains. Scale: $5 \mathrm{~mm}$

\section{Muweis (Central Sudan)}

Muweis is a small town located on the right bank of the Nile, $170 \mathrm{~km}$ north of Khartoum, in Central Sudan (western Butana). The city belonged to the Island of Meroe (a term coined by Strabo), a semi-desert landscape between the Nile, the Atbara and the Blue Nile rivers that was the heartland of the Meroitic kingdom (300 BC-AD 350) (Baud 2010b). Meroe, the capital, lies $50 \mathrm{~km}$ to the north of Muweis. Excavations directed by M. Baud (2006-2012) and M. Millet (2013-present) have revealed the existence of institutional, religious, domestic and industrial activities, each located in different areas of the town (Baud 2010a, 2014; Millet 2013). The region is subject to limited monsoon rains, so climatic conditions are more humid than in northern Nubia (present mean annual rainfall at Khartoum $=162 \mathrm{~mm}$, Walsh 1991:25) and organic materials not as well-preserved than in Qasr Ibrim. The seeds and fruit elements considered in this paper come from occupation layers relating to potential domestic activities (sector 3$)$ occurring during the Late Meroitic period $\left(2^{\text {nd }}-\right.$ mid $4^{\text {th }}$ centuries $\mathrm{AD})$. The plant remains, recovered by dry-sieving ( 21 and $0.5 \mathrm{~mm}$ meshes), are all charred. The study is still in progress and only preliminary results, focused on economic plants from seventeen samples (73 l of sediment) can be presented here (Fig. 3).

Sorghum and pearl millet grains dominate the archaeobotanical assemblage of economic plants. Winter cereals, hulled barley and emmer, as well as pulses (lens, Lens culinaris Medik.; cowpea, Vigna unguiculata (L.) Walp.) appear in less than half of the studied contexts. Fruit trees mainly comprise of the Christ's thorn jujube tree (Ziziphus spina-christi (L.) Desf.) and, to a much lesser extent of the desert date (Balanites 


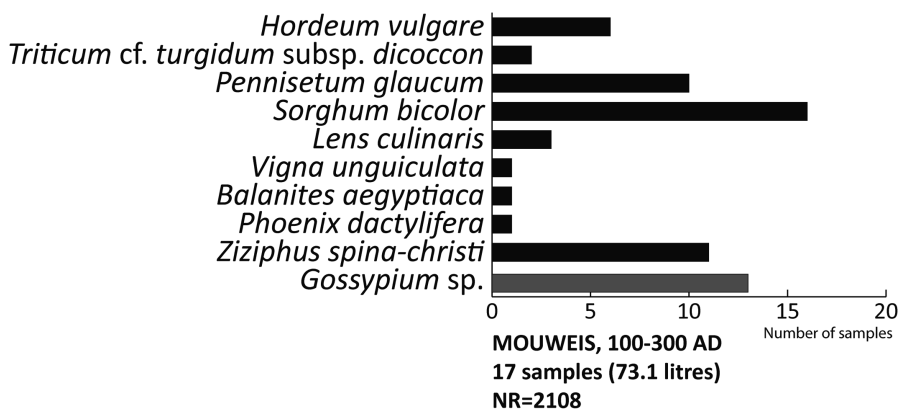

Fig. 3. Preliminary results of the analysis of charred seeds and fruits from Muweis (Central Sudan). Occurrence of the main economic taxa on 17 samples of the Late Meroitic period $\left(2^{\text {nd }}-\right.$ $4^{\text {th }}$ c. $\left.A D\right)$, sector 3 .

aegyptiaca Delile) and date palm (Phoenix dactylifera L.). Cotton is attested in about $75 \%$ of the samples. The direct radiocarbon date of two cotton seeds show that they belong, at the earliest, to the beginning of the $3^{\text {rd }}$ century AD (Table 3). Two deeper layers, still dating to the Late Meroitic period and also containing cotton seeds, have been radiocarbon dated using sorghum grains. The preliminary results indicate that cotton is present at Muweis during the $1^{\text {st }}-2^{\text {nd }}$ century AD. Currently, no earlier large archaeobotanical assemblage has been investigated from this site. Charred cotton remains (Fig. 4) are mainly represented by fragmented half-seeds, seed coat and cotyledons ( $93 \%$ of the total number of cotton remains), as well as some whole seeds (7\%) (Table 4), rarely covered with short fibre remains.

Table 3. Radiocarbon dating of plant materials from Muweis (Central Sudan), sector 3

\begin{tabular}{|c|c|c|c|c|c|c|c|}
\hline \multirow[t]{2}{*}{$\mathrm{Lab}^{\circ}$} & \multirow[t]{2}{*}{$\mathrm{US}^{\circ}$} & \multirow[t]{2}{*}{ Material } & \multirow{2}{*}{$\begin{array}{l}\text { Stratigraphic } \\
\text { periods }\end{array}$} & \multirow[t]{2}{*}{${ }^{14} \mathrm{C}$} & \multicolumn{3}{|c|}{$95.4 \%^{\mathrm{a}}$} \\
\hline & & & & & From & To & $\mathrm{p}$ \\
\hline \multirow[t]{2}{*}{ UBA-30480 } & \multirow[t]{2}{*}{3016} & \multirow{2}{*}{$\begin{array}{l}\text { Gossypium } \\
\text { sp., seed }\end{array}$} & \multirow[t]{2}{*}{ Late Meroitic } & \multirow[t]{2}{*}{$1722 \pm 48$} & 176 & 191 & 0.010 \\
\hline & & & & & 212 & 421 & 0.990 \\
\hline \multirow[t]{3}{*}{ UBA-30482 } & \multirow[t]{3}{*}{3034} & \multirow{3}{*}{$\begin{array}{l}\text { Gossypium } \\
\text { sp., seed }\end{array}$} & \multirow[t]{3}{*}{ Late Meroitic } & \multirow[t]{3}{*}{$1753 \pm 39$} & 143 & 155 & 0.013 \\
\hline & & & & & 167 & 195 & 0.036 \\
\hline & & & & & 210 & 389 & 0.951 \\
\hline UBA-30483 & 3044 & $\begin{array}{l}\text { Sorghum bicolor, } \\
\text { seed }\end{array}$ & Late Meroitic & $1834 \pm 38$ & 79 & 255 & 0.976 \\
\hline \multirow[t]{2}{*}{ UBA-30485 } & \multirow[t]{2}{*}{3071} & \multirow{2}{*}{$\begin{array}{l}\text { Sorghum bicolor, } \\
\text { seed }\end{array}$} & \multirow[t]{2}{*}{ Late Meroitic } & \multirow[t]{2}{*}{$1917 \pm 39$} & 2 & 180 & 0.958 \\
\hline & & & & & 185 & 213 & 0.042 \\
\hline
\end{tabular}

${ }^{\mathrm{a}}$ Calibration IntCal.09.14c (Reimer et al. 2013) 


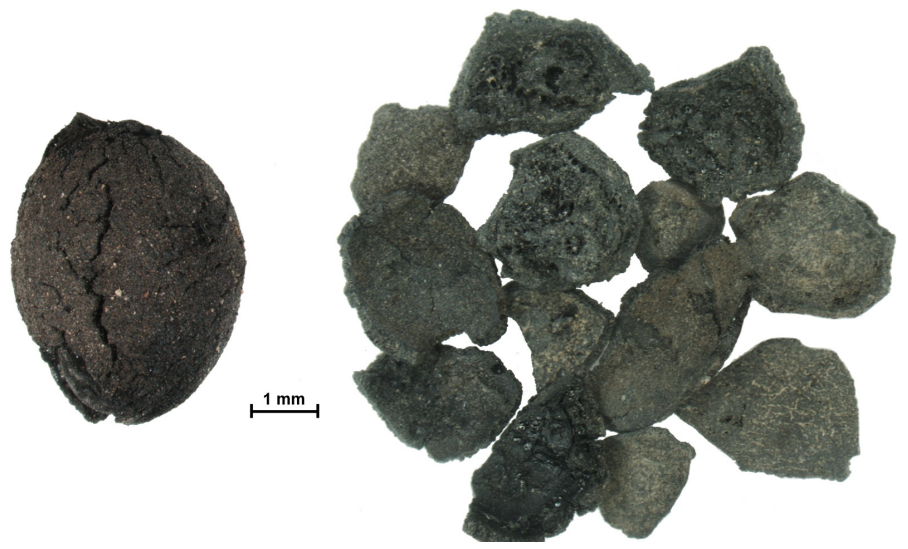

Fig. 4. Cotton finds from Muweis (Central Sudan). Charred whole cotton seeds (left), broken cotton seeds (right).

Table 4. Detail of charred cotton remains from Muweis (Central Sudan), sector 3, Late Meroitic

\begin{tabular}{l|l}
\hline & $1^{\text {st }}-3^{\text {rd }}$ centuries AD \\
\hline Number of samples containing cotton & 12 \\
\hline Gossypium sp., whole seed & $16(7 \%)$ \\
\hline Gossypium sp., seed fragment & $209(93 \%)$ \\
\hline
\end{tabular}

\section{Madâ'in Sâlih (North-Western Arabian Peninsula)}

The city of Madâ'in Sâlih, the ancient Hegra, is located in north-western Saudi Arabia, on a vast sandy plain surrounded by mountain massifs (Nehmé et al. 2006; Courbon 2008). Occupied since the $4^{\text {th }}-3^{\text {rd }}$ century BC (Durand and Gerber 2014), it was densely inhabited from at least the $2^{\text {nd }}-1^{\text {st }}$ centuries $\mathrm{BC}$ to the mid- $4^{\text {th }}$ century AD. From the $1^{\text {st }}$ century $\mathrm{BC}$ to the $1^{\text {st }}$ century AD, the town was at the southern limit of the Nabataean kingdom, on the route between Petra - the Nabataean capital - and Arabia Felix, before being integrated into the Roman Province Arabia (Arabia Petraea) after the annexation of the Nabataean kingdom in 106 AD. The work of the Franco-Saudi project, directed by L. Nehmé, D. al-Tahli and F. Villeneuve (2008-present) has revealed the existence of a residential area that was continuously inhabited from the earliest period, $4^{\text {th }}-3^{\text {rd }}$ century BC, to Late Antiquity (Nehmé et al. 2006, 2011). Monumental tombs carved into sandstone cliffs, mainly used during the $1^{\text {st }}-3^{\text {rd }}$ centuries AD, surround the residential area (Nehmé 2015). Low rainfall in the region, ranging between 50 and $100 \mathrm{~mm}$ per year, is compensated by the important presence of groundwater. It was largely exploited through wells, likely built during the Nabataean period, which were used to irrigate the cultivation area located to the north of the ancient city (Nehmé et al. 2006:59; Courbon 2008:49). The site is regularly subject to winter flash floods, which has prevented the preservation of organic material, with the 
notable exception of several monumental tombs where textile and leather pieces, as well as plant jewellery have been recovered (Bouchaud et al. 2015).

The archaeobotanical samples were taken from domestic assemblages (dumps, occupation layers, fireplaces) excavated inside the residential area. All the material is charred and was obtained through sieving and flotation using 2 and $0.5 \mathrm{~mm}$ meshes. The earliest layers $\left(4^{\text {th }} / 3^{\text {rd }}\right.$ to mid. $1^{\text {st }}$ centuries BC) are still under study. The preliminary observation of these early samples shows the presence of date palm, indeterminate cereals and fig remains. The samples from the following periods (from mid. $1^{\text {st }}$ century BC to mid. $4^{\text {th }}$ century AD) have been more thoroughly investigated (64 samples representing 7751 of sediment) and demonstrate the existence of more diversified cultivation. During the Classical Nabataean (mid. $1^{\text {st }}$ century BC-early $2^{\text {nd }}$ century $\mathrm{AD}$ ), hard wheat and hulled barley of 2-row and 6-row varieties (Hordeum vulgare subsp. distichon (L.) Körn/H. vulgare L. subsp. vulgare) are well attested. These two cereals, like the date palm, remain dominant until the end of the site's occupation. The Nabataeo-Roman occupation (early $2^{\text {nd }}$-end. $3^{\text {rd }}$ centuries AD) is characterised by the appearance of Mediterranean fruit trees, olive, and grapevine. At that time, cotton appears in one third of the studied samples. The end of the occupation (first half of the $4^{\text {th }}$ century AD) presents a similar taxonomical diversity. Cotton seeds are present in more than two-thirds of the samples (Fig. 5). Most cotton remains are of whole seeds. The radiocarbon dating of two of specimens (Table 5) confirm that cotton was present during the Nabataeo-Roman period, although we cannot exclude that it was

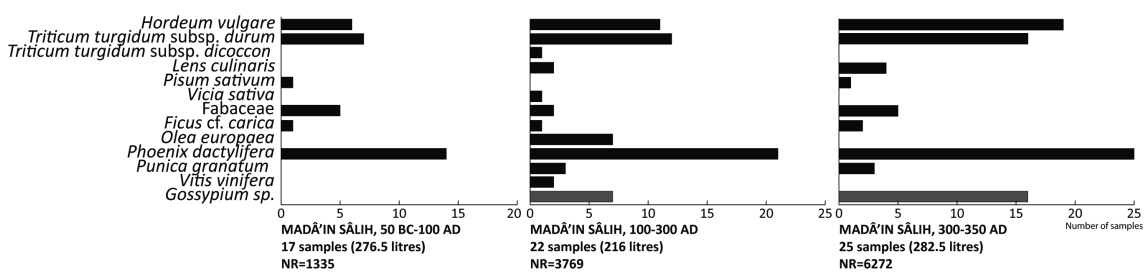

Fig. 5. Results of the analysis of charred seeds and fruits from Madâ'in Sâlih (Saudi Arabia). Occurrence of the main economic taxa from the Classical Nabataean to the Late Antique periods, residential area.

Table 5. Radiocarbon dating of plant material found at Madâ'in Sâlih (Saudi Arabia)

\begin{tabular}{l|l|l|l|l|l|l|l}
\hline Lab n $^{\circ}$ & US n & Material & $\begin{array}{l}\text { Stratigraphic } \\
\text { periods }\end{array}$ & ${ }^{14} \mathrm{C}$ & \multicolumn{3}{|l}{$95.4 \%^{\mathrm{a}}$} \\
\cline { 5 - 8 } & & & Nabataeo-Roman & $1815 \pm 30$ & $\mathbf{1 2 6}$ & $\mathbf{2 5 7}$ & $\mathbf{0 . 9 3 9}$ \\
\hline Lyon-9754 & 80124 & $\begin{array}{l}\text { Gossypium } \text { sp., } \\
\text { seed }\end{array}$ & & 284 & 290 & 0.006 \\
\hline Lyon-9755 & 80106 & $\begin{array}{l}\text { Gossypium } \text { sp., } \\
\text { seed }\end{array}$ & Nabataeo-Roman & $1850 \pm 30$ & $\mathbf{8 5}$ & $\mathbf{2 3 5}$ & $\mathbf{1}$ \\
\hline
\end{tabular}

${ }^{a}$ Calibration IntCal.09.14c (Reimer et al. 2013) 
present earlier (Bouchaud 2015). Fragmented seeds constitute $6 \%$ of the cotton assemblage for the $2^{\text {nd }}-3^{\text {rd }}$ centuries $A D$ and $39 \%$ for the last occupation period of the site (Table 6).

Table 6. Detail of charred cotton remains from Madâ'in Sâlih, Saudi Arabia

\begin{tabular}{l|l|l}
\hline & $2^{\text {nd }}-3^{\text {rd }}$ centuries AD & First half $4^{\text {th }}$ century AD \\
\hline Number of samples containing cotton & 7 & 16 \\
\hline Gossypium sp., whole seed & $30(94 \%)$ & $156(61 \%)$ \\
\hline Gossypium sp., seed fragment & $2(6 \%)$ & $98(39 \%)$ \\
\hline
\end{tabular}

\section{Dakhlah Oasis: Kellis and Trimithis}

The large settlement of Kellis (Islamic Ismant el-Kharab) is situated in the centre of the Dakhlah Oasis in the Western Desert of Egypt. Excavations started in 1986, under the direction of A.J. Mills and Colin Hope as part of the Dakhlah Oasis Project. They have revealed occupation mainly from the $1^{\text {st }}-4^{\text {th }}$ centuries $\mathrm{AD}$, though there is evidence of earlier (Ptolemaic) activities. The climate at Kellis is hyperarid with a present-day mean annual precipitation of $0.7 \mathrm{~mm}$. Underground aquifers feed to the surface through natural vents, springs, and bores. The exploitation of these aquifers developed with the Ptolemaic period introduction of advanced irrigation technology. The village expanded during the Roman period and comprised residential areas, as well as several temples, Roman baths, followed by early Christian churches, and extensive industrial areas. The excavations have yielded a rich archive of inorganic and organic remains, among them papyri, textiles, basketry and food remains, as well as the famous Kellis Agricultural Account Book, a collection of wooden tablets containing a set of agricultural accounts over a period of five years from the late $4^{\text {th }}$ century AD (Bagnall 1997; Thanheiser 2002). Spindle whorls and loom weights were found in every domestic structure excavated at Kellis, which suggests that spinning and weaving was carried out within the households (Bowen 2001, 2010).

Archaeobotanical samples were taken from within habitation areas occupied from the $1^{\text {st }}$ century AD to c. $360 / 380 \mathrm{AD}$, as well as in the temple complex and churches. Most samples were sieved through a $0.5 \mathrm{~mm}$ mesh and all significant matrices were also screened through larger meshes to recover rarer items. Approximately 700 samples, representing more than 10,000 plant remains, have been analysed to date.

The plant macro-remains found, mainly desiccated, show that the agricultural life during the $1^{\text {st }}-4^{\text {th }}$ centuries was based on various winter and summer crops, including free-threshing wheat, barley and pearl millet, and pulses, especially lentil and fava bean (Vicia faba L.). Fruit tree production is dominated by date palm and by Mediterranean fruits such as olive, fig (Ficus carica L.), grape and minor taxa such as almond (Prunus dulcis (Mill.) D. A. Webb), pomegranate (Punica granatum L.), and citron (Citrus cf. medica L.). Vegetables and herbs remains are numerous and include onion (Allium cepa L.), garlic (Allium sativum L.), fennel (Foeniculum vulgare L.), rosemary (Rosmarinus officinalis L.) and coriander (Coriandrum sativum L.). Oil and fibre plants 
are mainly represented by safflower (Carthamus tinctorius L.), flax/linen and cotton. The majority of these crops, including cotton, are listed as locally grown in the Kellis Agricultural Account Book mentioned above. (For more details, see Thanheiser 2002; Thanheiser et al. 2016).

Cotton remains from Kellis consist of desiccated seeds, whole and fragmented, as well as bolls and empty capsules. Seeds are much more abundant than bolls. Cotton remains always occur together with another summer crop, pearl millet, which is present in greater proportions (Thanheiser et al. 2016).

Amheida, known as Trimithis during the Roman Period, is located in the western part of the Dakhlah oasis, some $20 \mathrm{~km}$ north-west of Kellis. The site has a long occupational history and is dominated by a large hill surmounted by a temple that was built and rebuilt over many centuries. Amheida reached its greatest size under Roman rule (approximately $1^{\text {st }}-4^{\text {th }}$ centuries AD) (Boozer 2015a). House B2, which yielded the archaeobotanical remains described below was located in the northeast sector of the city, which was composed of domestic and industrial structures. Sediment samples and hand-picked specimens were taken from sealed deposits rich in organic material, securely dated to the $3^{\text {rd }}$ century AD, and less reliable contexts such as open courtyards. Sediment samples were sieved using a $0.5 \mathrm{~mm}$ mesh. Plant remains are charred and desiccated. The organic material is less well-preserved than in Kellis, probably because of more humid local conditions. Nevertheless, the archaeobotanical inventory of house B2, comprised of more than 17,000 items, contains almost all plants typical for a household of the $3^{\text {rd }}$ century $\mathrm{AD}$ in the Dakhlah Oasis. The assemblage includes a variety of winter and summer staple crops, especially hard wheat and hulled barley along with emmer, pearl millet, lentil, and fava bean. Vegetables, herbs, and spices include coriander, dill (Anethum graveolens L.), celery (Apium graveolens L.) and other items mainly originating in the Near East. Grape, olive, fig, and date are the most common fruits, but rare remains of other fruits and nuts, such as pine nut (Pinus pinea L.), peach (Prunus persica (L.) Batsch), sebesten (Cordia myxa L.), pomegranate, watermelon (Citrullus lanatus (Thunb. Matsum. \& Nakai) and melon (Cucumis melo L.) were also found.

Oil and fibre plants include flax, sesame (Sesamum indicum L.), safflower, and cotton. Along with the cleaned products, processing waste such as cereal chaff and flax capsules were recorded (Thanheiser and Walter 2015). The botanical remains of cotton from the house B2 consist of 58 desiccated and 47 charred whole seeds. No capsules are present (Thanheiser and Walter 2015).

\section{Other Archaeobotanical Finds and General Considerations}

Several other sites in north-eastern Africa have provided archaeobotanical cotton remains. The Meroitic site of Hamadab in Central Sudan, to the north of Muweis, has revealed quantities of cotton seeds in $1^{\text {st }}-3^{\text {rd }}$ century AD domestic layers (work in progress, see mention in Fuller 2014:173). The Roman fort of Al-Zarqā', ancient Maximianon, in the Eastern desert of Egypt, provided 24 desiccated seeds found in trash layers mostly dated to the $1^{\text {st }}-2^{\text {nd }}$ century $\mathrm{AD}$, with one item from a late $2^{\text {nd }}$ to early $3^{\text {rd }}$ century AD layer (Newton unpublished). The archaeobotanical survey of the 
oasis of Jerma, ancient Guarama in southern Libya (Fezzan), showed the regular presence of charred complete and partial remains of cotton seeds from the $2^{\text {nd }}$ to the $9^{\text {th }}$ century. Direct radiocarbon dating confirms the presence of cotton by the $3^{\text {rd }}-4^{\text {th }}$ century AD (Pelling 2013:482). In the Kharga oasis, western Egypt, the necropolis of the ancient town of Kysis (present Douch) (Dunand et al. 1992; Tallet et al. 2012) and the contemporaneous urban sites of el-Deir (Tallet et al. 2012:127; Bouchaud and Clapham personal communication) and Qasr el-Sumayra (Clapham personal communication) offer desiccated cotton seeds probably dating from the $4^{\text {th }}$ century AD. However, radiocarbon dating should be undertaken on the material from Kysis and el-Deir to confirm the chronology of the finds as they both come from disturbed contexts. Finally, charred seeds have been found at Aksum, Ethiopia in domestic contexts of the $6^{\text {th }}-$ early $7^{\text {th }}$ centuries with other Near Eastern and African annual and perennial plants (Boardman 1999) ${ }^{2}$.

To sum up the archaeobotanical finds, the charred cotton items found in the different sites only includes seeds, whole or fragmented, whereas the desiccated material also includes capsule elements. The oldest reliable archaeobotanical find of cotton come from Qasr Ibrim in Lower Nubia and is associated to a period during or immediately after the Roman occupation (end $1^{\text {st }}$ century $\mathrm{BC}-1^{\text {st }}$ century AD). Cotton seeds appear at the end of the $1^{\text {st }}$ century in Nabataeo-Roman contexts in western Arabia and under Meroitic rule in Central Sudan, then in Egyptian oases in the Western Desert from the $2^{\text {nd }}-3^{\text {rd }}$ century AD onwards. Almost all the cotton records come from domestic contexts in towns and villages, and potentially indicate local cultivation. At Maximianon, local cultivation of cotton should not be considered because of the lack of water and the military status of the site. The seeds, perhaps used in packing material for the transport of delicate materials, must have come from elsewhere.

\section{Textile Finds}

Down the chaîne opératoire, it is interesting to also consider the finished cotton textiles - fabrics and clothing - as well as their trade, to obtain complementary data on the geographical and chronological scope of cotton production. However, the detailed examination and interpretation of these textile finds deserve a complete study that is beyond the scope of this paper.

Aside from isolated finds of cotton fibres in Chalcolithic Jordan (Betts et al. 1994), which should be re-examined in the light of new radiocarbon dating methods to confirm the antiquity of this isolated discovery, the majority of cotton textiles appear on both sides of the Red Sea on sites dated from the $1^{\text {st }}$ century AD onwards.

\footnotetext{
${ }^{2}$ We decided not to detail and comment later data as it is out of the scope of the present article. Discoveries of Medieval cotton seeds in Africa and Middle East are few and localized at Myos Hormos in Egypt (Van der Veen 2011), Nauri (Fuller and Edwards 2001) and Hisn al-Bab (Clapham, unpublished) in Nubia, Dia in Mali (Murray and Cappers 2007), Volubilis in Marocco (Fuller et al. forthcoming), Chwaka in Tanzania (Walshaw 2010; cited in Van der Veen 2011:114) and various sites along the Euphrates river (Samuel 2001) and in Turkey (Miller 1998, 2010; Van der Veen 2011).
} 
Nubia and Central Sudan present the largest corpus of cotton textiles (Fig. 1, Table 1). Most of them were found in funerary contexts and, to a lesser extent, in domestic settlements, especially in Qasr Ibrim. The majority of preserved fabrics comes from Lower Nubia, thanks to the hyper-arid climate of the region and extensive archaeological activity due to the UNESCO International Rescue Nubia Campaign before the completion of the Aswan High Dam. Outside of Lower Nubia, numerous sites in Upper Nubia, Central Sudan and the southern region of the Gezira also offer a rich corpus of tools, spindle whorls, loom weights, weaving combs and needles, demonstrating the great extent of the textile craft in these areas (Yvanez 2016). In the $1^{\text {st }}$ and $2^{\text {nd }}$ centuries AD, Nubian and Sudanese textiles, dominated until then by linen (as in Egypt) witnessed the important introduction of cotton, which subsequently represented more than half of textile occurrences in several major funerary and residential sites (Yvanez 2016). This is the case in Lower Nubia - at Karanog (Griffith and Crowfoot 1934), Aksha (Vila 1967), Qustul and Ballana (Mayer-Thurman and Williams 1979:36), and Qasr Ibrim (Plumley et al. 1977; Anderson and Adams 1979; Wild and Wild 2008, 2009, 2014b) — as well as in Upper Nubia and Central Sudan, at Saï (Yvanez 2012) and Meroe (Massey 1923; Griffith and Crowfoot 1934; Dunham 1963). All these sites present large quantities of cotton textiles characterised by S-spun threads and a very specific style of decorated fabrics, which prompted the first textile specialists (Griffith and Crowfoot 1934) to describe a Meroitic style and assume the Nubian origin of a large part of these specimens. Except for the Roman cotton thread from Qasr Ibrim mentioned above, none of these textiles is radiocarbon dated and most of them are attributed to the end of the Classic and Late Meroitic periods, from $1^{\text {st }}$ to $4^{\text {th }}$ century $\mathrm{AD}$. The presence of unbaked clay loom-weights in many Meroitic settlements, as well as flat-woven starting borders preserved on a number of textiles, both point to the use of the vertical warp-weighted loom (Gleba and Mannering 2012; Wild and Wild 2014b: 76). Cotton textiles undoubtedly played a very important role under Meroitic rule. The available data for the following periods, Post-Meroitic, Christian and Islamic periods, that mainly correspond to funeral contexts and small corpuses, show that production likely declined-when the wool from sheep and camel were favoured in both Lower (Adams 2007; Wild and Wild 2014b) and Upper Nubia (Adams et al. 1999; Vogelsang-Eastwood 2001).

In Egypt, the excavation of Bereneke and Myos Hormos provided an important sample of cotton textiles. During Roman times, the two sites were the main active harbours on the Red Sea and were both implicated in the intensive trade between the Roman Empire and India. The discoveries comprise fragments of cotton sails dated to the late $1^{\text {st }}$-early $2^{\text {nd }}$ century AD from Myos Hormos (Handley 2004; Whitewright 2007), sail remnants and pile sleeping mats, dated to the $1^{\text {st }}$ century AD, from Berenike (Wild and Wild 2001; Wild 2013; Wild and Wild 2014a, c). A smaller corpus of cotton textiles dated to the $4^{\text {th }}$ century AD was also found at Abu Sha'ar (Bender Jørgensen and Vogelsang-Eastwood 1991; Bender Jørgensen 2004, 2006). Based on the technical studies of fabrics woven with Z-spun yarns, and critical analysis of written sources, it is assumed that these items came from India (see below and Wild and Wild 2014a, c). Other pieces, notably those woven from S-spun yarns, are considered of possible Nubian or Egyptian manufacture (Wild 1997; Wild and Wild 2014a:211). 
One undated site in the Nile valley (el-Hibeh, Ryesky 1984) and several sites in the Great Oasis (Dakhlah and Kharga oases combined) attest the presence of cotton textiles alongside wool and linen in long-lived Egyptian settlements. These include the $2^{\text {nd }}-3^{\text {rd }}$ century AD at Kellis (Livingstone 2009, 2015) and Trimithis (Boozer 2015a) in the Daklheh Oasis and during the $3^{\text {rd }}$ and $4^{\text {th }}$ century AD at Kysis (Dunand et al. 1992:232; Tallet et al. 2012:126), El-Deir (Letellier-Willemin and Moulhérat 2006; Letellier-Willemin and Médard 2012) and 'Ayn Umm Dabadib (Jones and Oldfield 2006). The finds were excavated from households, funerary and cultic (temple) contexts. At Kellis, textiles were found in the same habitation areas where cotton seeds were recovered (see above), showing higher frequencies of cotton threads than linen and wool specimens. The cotton material includes S-spun curtains and other locally manufactured household textiles. The presence of characteristic textile fragments with corded (multi-strand twining) starting borders indicates the possible use of a vertical two-beam loom for the manufacture of these specific cotton fabrics. Several Z-spun cotton fabrics with blue resist-dyed patterns probably represent imported items from India (Livingstone 2009).

The cotton textile evidence from western Arabia is much less widespread than in Sudan and Egypt. Madâ'in Sâlih (Bouchaud et al. 2011, 2015), where cotton seeds were found (see above) provided a few pieces of cotton in Nabataean tombs $\left(1^{\text {st }}-3^{\text {rd }}\right.$ century AD), along with linen and wool fabrics. All the cotton textiles are of Z-spun yarns. At the same time, several southern Near Eastern sites witness the presence of cotton threads and textiles in funerary contexts (Fig. 1, Table 1), in regions around the Dead Sea (Bellinger 1962; Rahmani 1967; Sheffer and Tidhar 1991; see a review in Wild 1997; Müller et al. 2003, 2004), in Jordan (Granger-Taylor 2000, 2007) and especially in Palmyra, where cotton evidence seems to increase through time (Schmidt-Colinet 1995; Stauffer 2000). Both Z-spun and S-spun threads are recorded and nowhere is indicated a clear dominance of one type over the other. Apart from Madâ'in Sâlih, where the textiles' local origin was tentatively suggested (Bouchaud et al. 2011), these textiles are generally considered imported, as no other evidence, such as plant remains, attests their potential local production. The importance of cotton textiles increases from the $8^{\text {th }}$ century onwards around the Dead Sea, as demonstrated by the discoveries in the Jericho region (Shamir 2015; Shamir and Baginski 2013) and in the Aravah valley (Shamir and Baginski 2014). For this later period authors are more disposed to consider that the cotton was grown locally (Shamir and Baginski 2013:82).

\section{The Texts}

Different types of written sources evoke the agricultural and textile production of cotton. They mainly refer to Egypt and in a few cases to Nubia, Sudan and the Horn of Africa. The earliest and also the most vague account, was written by Pliny the Elder who describes in the $1^{\text {st }}$ century AD what he called 'wool-bearing tree', gossypinus or xylon, and states that it grows on the Arabian side of Upper Egypt and Ethiopia (Natural History, 19.14). Julius Pollux repeated this information in his Greek thesaurus of the $2^{\text {nd }}$ century AD (Onomasticon 6.75). Because of the occasional uncertain words, it is difficult to have confidence in the geographical comments, although other lines of 
evidence from Lower Nubia, central Sudan and Ethiopia (see below) suggest that they are accurate. At the same time, the Periplus Maris Erythraei (PME) states that Indian cotton cloth and garments of different qualities were exported to the main ports of Arabia and Africa (see below and Casson 1989).

The earliest reliable and precise textual mention of cotton cultivation in Egypt comes from the oasis of Kharga. A land registry (P. Iand. 7. 142) dating to 164-165 $\mathrm{AD}$, referring to lands around Kysis (present-day Douch, southern Kharga), contains one mention of cotton ("wool tree") among a list of economic trees (olive tree, date palm, unspecified fruit trees). About two centuries later, the Kellis Agricultural Account Book $(K A B)$, documenting the income and expenditures of a land estate at Kellis, in Dakhlah oasis, contains few but informative references to cotton. The text indicates that two tenant farmers paid their rent to the landowner in cotton or, when they could not supply cotton, substituted other commodities ( $K A B 547,556,720 ; 1484)$. The estate allocated one lithos (unit of weight) of cotton to a woman for weaving (KAB 558) (Bagnall 1997). Besides these specific references to cotton, it is evident from the Kellis texts that household textiles were manufactured in the village. Several business accounts attest to a weaving workshop in the mid to late $4^{\text {th }}$ century AD (Gardner et al. 1999 ) and the $K A B$ mentions a clothes-weaving shop (Bagnall 1997, 153). Cotton is also mentioned in two ostraca from the same site. O. Kellis 68 and O. Kellis 69, dated to circa 237 and 257 AD respectively, are two receipts for six years of harvests mentioning substantial quantities of cotton (Worp and Hope 2004; Bagnall 2008). Cotton production is also well attested during the $4^{\text {th }}$ century AD in Kharga oasis. One ostracon from the temple of Kysis (O.Douch 1.51) lists five names of women associated with cotton who are interpreted as spinners or weavers (Cuvigny and Wagner 1986). O.Douch 5.537 and O.Douch 5.634 mention quantities of cotton (Wagner 2001) and O.Douch 4.381, from the Kysis military area, is an order to deliver cotton as a payment of Annona militaris, here a direct requisition in kind redistributed to soldiers (Wagner 1999). Finally, two of ostraca found at Amheida (Dakhlah oasis), O.Trim 38 and O.Trim 44 indicate the presence considerable quantities of cotton (Bagnall and Ruffini 2012). Indeed, based on a calculation of equivalence between the lithos and the Roman pound, the maximal volume recorded (in O.Trim 44), 26 lithoi, is equivalent to more than $200 \mathrm{~kg}$ of cotton - a very large quantity, when considered in terms of volume (Bagnall 2008).

Beside these administrative accounts that demonstrate the local production of cotton in the Great Oasis, one administrative document and several private letters of the $2^{\text {nd }}-3^{\text {rd }}$ century $\mathrm{AD}$ of unknown or dubious origin attest the circulation of cotton textiles between the oases of the Western desert and the Nile valley. One mentions the sending of a cotton garment from Psobthis (probably the capital of Bahariya oasis, Western desert) to Oxyrhynchus in the Nile valley ( $S B$ 6.9025). Another, of unknown origin, mentions the making of garments from cotton thread ( $S B$ 6.9326) (see comment in Bagnall 2008). An administrative document of unknown origin, P.Lond 3.928, presents a list of taxed goods in which cotton appears (Bagnall 2008; Winter and Youtie 1944). One papyrus found at Oxyrhynchus but of unknown origin (P. Oxy. 59.3991) mentions a cotton garment (Bagnall and Cribiore 2006). Finally, one of the private letters of a $2^{\text {nd }}$ century $\mathrm{AD}$ archive belonging to Roman citizens (P.Mich. 8.500.7), found at Karanis, refers to cotton goods that would have been sent from 
Rome, according to the translators. However, this interpretation has been disputed (Bagnall 2008). Despite the fragmentary and limited character of these data, their repetition highlights that cotton was available in the small oasis of Bahariya and the nomes of Oxyrhynchus (Nile valley, Middle Egypt) and Arsinoe (Fayum) (Bagnall 2008).

There are no written sources available alluding to cotton in the western Arabian Peninsula and in the southern Near East, and only one inscription has been found south of Egypt. The epigraphic record of the raid of the Aksumite king Ezana against the Meroitic kingdom, dated to the mid- $4^{\text {th }}$ century AD, mentions the destruction of the provisions of grain and cotton (Littmann 1913, see comment in Zeitschrift der Deutschen Morgenländischen Gesellschaft 67:701). According to geographical arguments, some scholars place these agrarian stocks to the north of the island of Meroe (Central Sudan), at the junction between the Nile and the Atbara rivers (Török 1988).

To sum up, the texts clearly indicate the importation of Indian cotton to the main ports of Arabia and Africa and being transported to Egypt and perhaps the Mediterranean world. The cultivation and processing of cotton in Kharga and Dakhlah oases, as well as the circulation of cotton textiles between these oases and the Nile valley, are visible from the mid- $2^{\text {nd }}$ century $\mathrm{AD}$ onwards. The quantities indicated in the documentation suggest the existence of substantial volumes of cotton used as payment in kind, partly for the army provisioning. Besides these Egyptian centres, only one epigraphic inscription attests to the existence of cotton stocks within the Meroitic kingdom, in Central Sudan.

\section{Cotton Dynamics in North-Eastern Africa and Western Arabia: Facts and Limits}

The distribution of archaeobotanical, textile and written records in north-eastern Africa and western Arabia highlights spatial and temporal production and trade dynamics of cotton. The evidence must be understood as hypothetical and incomplete because of various degrees of preservation of the organic remains and the methodological biases specific to each scientific discipline involved. Furthermore, much of the data are not useable because of imprecise dating, except when direct radiocarbon dating or secured chronological settings can be obtained (for example, direct dates on papyri and secure archaeological contexts). Our understanding of the different agricultural production centres varies depending on the coverage of each type of data, leading to heterogeneous degrees of knowledge across the region under study. Cotton cultivation and exploitation are securely attested when contemporary archaeobotanical, textile and textual data are all available on the same site, for instance at Kellis and Amheida, or when the textual evidence clearly refers to the local cultivation of cotton, as in Kysis. Little doubt also remains when cotton represents a high proportion of the archaeological textiles and/or archaeobotanical corpus, as evident in Qasr Ibrim, Muweis, Hamadab, Jerma and Madâ'in Sâlih.

Thus, if we exclude the dubious early record from Afyeh in Nubia, dated from the $3^{\text {rd }}$ millennium $\mathrm{BC}$ (see above), the oldest reliable use of cotton found to date in north-eastern Africa comes from Roman Qasr Ibrim, in Lower Nubia, at the end of the 
$1^{\text {st }}$ century $\mathrm{BC} / 1^{\text {st }}$ century $\mathrm{AD}$. In parallel, textiles appear in several tombs in Lower and Upper Nubia as well as Central Sudan, from which technical characteristics suggest that they were made locally. We therefore assume small-scale cotton production to have occurred in several Nubian and Sudanese regions at that time, as described by Pliny. However, no plant macro-remains that could have supported the textile evidence have been discovered in Central Sudan for the Early $\left(3^{\text {rd }}-1^{\text {st }}\right.$ centuries BC) and Classic Meroitic $\left(1^{\text {st }}\right.$ century BC$-1^{\text {st }}$ century AD) periods. This situation is the result of two main factors: the occurrence of seasonal rains in these southern latitudes, and the general lack of well-preserved archaeological contexts of these periods in the region. Cotton production centres emerge in the western oases of Egypt in the mid- $2^{\text {nd }}$ century $\mathrm{AD}$ (at least) in Kharga oasis, and later in Dakhlah oasis during the $2^{\text {nd }}-3^{\text {rd }}$ century, as well as in Jerma (Libya). The chronology is similar in north-western Arabia, where cotton seeds and textiles from Madâ'in Sâlih may represent local production as early as the $1^{\text {st }}$ century AD. The textiles from this site, potentially locally produced, pose a new challenge as they are all woven with Z-spun yarns, which are generally attributed to Indian manufacture. Finally, the question of the local introduction of cotton plants at that time remains open for several other areas where we only know the presence of cotton fabrics: in the Fayum, in Bahariya oasis and around Oxyrhynchus in Middle Egypt, or around the Dead Sea, all places where cotton production is well attested a few centuries later (see for an example at Jericho, Shamir and Baginski 2014).

The accumulation of different types of evidence provides an increasingly complete description of cotton history in the Old World. After India in the $3^{\text {rd }}$ millennium BC (Fuller 2008), and the Mesopotamia (Muthukumaran 2016) and Persian gulf (Tengberg and Lombard 2001; Bouchaud et al. 2011) during the $1^{\text {st }}$ millennium BC, several groups in north-eastern Africa and western Arabia developed centres of cotton cultivation and textile production, probably at the turn of the $1^{\text {st }}$ century $\mathrm{BC}$ and the $1^{\text {st }}$ century AD. This process becomes clearly visible after the $2^{\text {nd }}-3^{\text {rd }}$ century, perhaps suggesting an increase in cotton production at that time. As the body of evidence remains limited, we cannot affirm the preponderance of cotton fibres in the economic life of the whole region, apart from Nubia and Central Sudan where cotton received the favours of the Meroitic elites during the first four centuries AD (Mayer-Thurman and Williams 1979; Adams 2007; Yvanez 2016).

\section{Management Practices of a Perennial Tropical Crop}

\section{The Cotton Tree}

We have very little reliable information on the cultivation of cotton during Antiquity, but scattered data allow us to assume that cotton mainly grew as a perennial plant (Decker 2009; for the potential emergence of annual varieties, see Brite and Marston

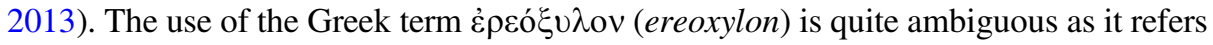
either to the plant or to the fruit itself. However, the mention of cotton among other perennial crops (olive, other fruit trees and palms) in the $2^{\text {nd }}$ century AD papyrus from Kysis in Kharga oasis (P. Iand. 7. 142) clearly shows that the plant should be a perennial in this case. Apart from this mention, only more recent data can be used. 
Ibn al-'Awām, an Andalousian agronomist, in his $12^{\text {th }}$ century treaty on agriculture, describes the cultivation of cotton based on both older treaties and local experience in Al-Andalūs. While it is not actually described as a tree, the plant is said to live several years, yielding a crop of fibres every year and in Egypt the plant can reach the size of a fig tree (Ibn Al-'Awām, Kitab al-Filāha, trad. J.-J. Clément-Mullet revised by El Faïz (2000). During the $16^{\text {th }}$ century, Prospero Alpini reports that the Egyptian people imported herbaceous cotton from Syria and Cyprus whereas local Egyptian cotton is described as a shrub, needing several years to mature but producing fewer fibres than the herbaceous cotton (Prospero Alpini, De Plantis Aegypti liber XVIII, De Fenoyl (2007)). He records in another volume that both herbaceous and perennial cottons grew in Egypt (Historiae Aegypti Naturalis, De Fenoyl and Sauneron 2007). Finally, cotton tree cultivation was still recently practiced in Nubia (Bond 1925), southern Sudan (Crowfoot 1931) and Ethiopia (Nicholson 1960) in the $20^{\text {th }}$ century, where it was grown for periods of three to five or more years (Nicholson 1960). So, if we consider that cotton in north-eastern Africa and western Arabia grew as a tree, the use of ecological data (period of blossoming and maturing, water and soil requirement, insect resistance, etc.) belonging to modern annual cotton plant becomes irrelevant. More specifically, this raises the question of water needs and irrigation requirements.

\section{Was Ancient Cotton a Thirsty Plant?}

Modern annual cotton varieties require a minimum of $500 \mathrm{~mm}$ from rain or irrigation between germination and boll formation (Eyhorn et al. 2005). As far as we know, there are no available assessed ecological data concerning the perennial varieties. According to Ibn al-'Awām (op. cit.), cotton was watered in Spain, Sicily, Egypt, Palestine, Syria, the Hijâz and Mesopotamia (Basra). It was grown under either rainfall or irrigation in modern Ethiopia (Nicholson 1960). Old world species (G. arboreum, G. herbaceum), regardless of annual or perennial forms, are known to be more resistant to drought than the American ones (G. hirsutum and G. barbadense) (Eyhorn et al. 2005). The results from an archaeogenomic study on $4^{\text {th }}$ century AD cotton seeds from Qasr Ibrim suggest that cotton, like other crop species found at this site (Palmer et al. 2009), may have been locally adapted to extreme environmental stress (Palmer et al. 2009). Even considering potential lower water needs for these old cottons, annual rainfall in north-east Africa and western Arabia does not exceed $100 \mathrm{~mm}$ today as was likely in the past (Walsh 1991 for Sudan, Sanlaville 2000 for Egypt and Arabia) suggesting that rain fed cotton cultivation was almost impossible. Cotton requires water input during the growing season, i.e. spring and early summer depending on the variety, and should not be waterlogged as the fruits form. In central Sudanese regions, which have a limited monsoon, as in Muweis, cotton would benefit during its growing season from irregular summer rains. Elsewhere, winter rainfall is useless for the cotton growth cycle and water management must have been carried out. In the Nile valley, as around Qasr Ibrim, Hamadab and Muweis, another factor to consider is that flooding occurred between July and November when cotton fruits are mature and therefore water should be avoided. Thus, if we take into account that cotton was probably perennial, it is likely that it was cultivated in fields away from the land susceptible to Nile flooding 
(Fuller 2015). In Lower Nubia, it is assumed that the spread of cotton cultivation was intrinsically linked to the development of mechanical irrigation systems, and especially to the introduction of the waterwheel or saqia (Wild et al. 2007; Fuller 2014, 2015). Archaeological evidence, mainly from Lower Nubia, does not indicate the presence of saqia before the $3^{\text {rd }}$ century AD (Edwards 1996, 2004:159), about two centuries after the first explicit evidence of local cotton cultivation. This means that these first attempts would have been carried out with existing irrigation equipment, including the shaduf, or alternative methods. For instance, in Upper Nubia, where the Nile course often changes, agronomic observations at the beginning of the $20^{\text {th }}$ century revealed that perennial cottons grew sheltered in pits dug in shallow sand covering the ancient alluvial plain. Subsequently, these cotton trees, some of them reaching ten-years of age, needed no care or watering until the harvest (Bond 1925: Figs. 4 and 5, plate VII). Although the more stable Nile course in Lower Nubia or Central Sudan makes it less suitable for that practice, it illustrates first, the existence of perennial cotton able to sustain relatively dry conditions and secondly, the human ingenuity in dealing with ecological conditions to enhance a priori unfavourable lands with a minimum of technical devices.

Beside these considerations, it seems logical to consider that the development of complex irrigation systems should enhance the productivity of crops. In Lower Nubia, the emergence of the saqia may be correlated with an apparent increase in cotton cultivation during the $3^{\text {rd }}$ century AD (Wild et al. 2007; Clapham and Rowley-Conwy 2009; Fuller 2014, 2015). In Dakhlah oasis, irrigation systems composed of wells and canals spread during the Ptolemaic period, before the visible emergence of cotton. In the Kharga oasis, a complex irrigation system was probably established in the northern region, at El-Deir, and generalised in the southern area in the $5^{\text {th }}$ century $\mathrm{BC}$, which was further expanded and reconfigured during the Roman period (Chauveau 2005; Gonon et al. 2005; Bravard et al. 2016). At Madâ'in Sâlih, about one hundred wells were built during the Nabataean period ( $1^{\text {st }}$ century $\mathrm{BC}-1^{\text {st }}$ century AD) (Courbon 2008), before the arrival of cotton. No technical innovation of the irrigation system is visible during the entire occupational sequence. In light of these data, it seems quite clear that the chronology of cotton introduction does not follow nor has it had direct effects on the history of irrigation technology. It may attest to the small scale of cotton cultivation at its onset and/or adequacy of extant irrigation techniques.

\section{Farming Calendar and Agricultural Changes}

Cotton, as well as sorghum, pearl millet and cowpea are tropical or sub-tropical crops whose periods of growth, maturity and harvest occur from spring to late summer. Their introduction to north-eastern Africa and western Arabia demonstrates agricultural changes as they were added to an existing agricultural regime mostly based on winter Near Eastern annual crops, such as barley, emmer/hard wheat, flax which weresown in autumn and harvested in the spring. However, several elements demonstrate that some crops with summer flowering and fruiting periods were already under cultivation. First, a range of summer crops that are little visible in the archaeobotanical, textual and iconographical records such as onion, garlic, cabbage (Brassica oleracea L.), lettuce (Lactuca sativa L.), watermelon, chickpea (Cicer arietinum L.), broomcorn millet 
(Panicum miliaceum L.), foxtail millet and sesame were present in Egypt and in parts of the Near East before the $1^{\text {st }}$ millennium AD (Aubaile-Sallenave 1984; Van der Veen 2011:76; Zech-Matterne et al. 2015). Castor-oil-plant (Ricinus communis L.), a short-lived perennial tropical plant, had already been introduced to the Western Desert oases of Egypt during the $1^{\text {st }}$ millennium BC. It is recorded in the $7^{\text {th }}$ century BC in Bahariya oasis and was especially significant in the agricultural economy of the southern Kharga oasis from the $5^{\text {th }}$ century BC, where it may have played the role of a cash crop (Agut-Labordère and Newton 2013; Newton et al. 2013). The date palm, pollinated in February-March and harvested in August-September, was also a significant staple growing at the time of introduction of these new crops (see Bouchaud 2015 for northern Arabia; Murray 2000a, b; Tengberg and Newton (2016) for Egypt and Nubia). Thus, the emergence of new tropical plants in these regions results less in an extension of the farming season, as has been suggested before (Watson 1983), than in an intensification of the summer season farming. The various archaeobotanical examples show that this process took various forms. Tropical plants played a dominant role in Nubia and Central Sudan from the Meroitic period onwards to the detriment of winter cereal crops. For sites located in the Nile valley, where perennial and summer crops should be cultivated away from the Nile flood, it resulted in an optimisation of the already cultivated plots - for date palm cultivation for instance-and/or in an expansion of agricultural land. As far as we know, no reliable written or archaeobotanical data witness the existence of these new tropical crops on sites located in Middle and Lower Egypt. At those latitudes, they seem to be restricted to the western oases of Egypt, i.e., environments not subject to the annual flood and with year-round access to water. In Dakhlah oasis (Kellis, Trimithis), winter crops remained important even after the introduction of tropical plants. A diversification of crop inventories ensued, at least for cereals and textile production, implying risk-minimization while requiring an increase in labour for agricultural and textile processing (Clapham and Rowley-Conwy 2009; Fuller 2014; Thanheiser et al. 2016). The presence of cotton in the oasis of Madâ'in Sâlih for about two centuries shows that the plant was well adapted. However, it is the only reliable tropical crop attested at that time in the region (Bouchaud 2015), except perhaps sesame (Zech-Matterne et al. 2015). Others, like sugar cane (Saccharum officinarum L.), or rice (Oryza sativa L.), seem to develop around the Dead Sea several centuries later by the $10^{\text {th }}-12^{\text {th }}$ centuries AD (Watson 1983; Samuel 2001) whereas sorghum or pearl millet only extended into southern Arabia probably during the Medieval period (Boivin and Fuller 2009; Varisco 2009). Compared to Egyptian oases, Nubia and the Sudan, it seems that tropical crop introduction during Nabataeo-Roman times in Arabia was limited.

Three archaeological markers that have been described demonstrate important agricultural changes: new crops that defined genetic innovation (see Kirch (1994), summarised in Thurston and Fisher (2007:11); increase in the area of land under cultivation showing an expansion process (Morrison et al. 1996:587); and progress in the technical irrigation devices reflecting long-term investments (Brookfield 1984). These are all present in Lower Nubia from the $3^{\text {rd }}$ century AD, and they probably accompanied broader societal changes. For instance, it has recently been proposed that agricultural changes in the Meroitic kingdom, clearly visible in the north (Lower 
Nubia) and assumed in the south, contributed to the collapse of the Meroitic state since they allowed regional economic independence of the regional successor states (Fuller 2014, 2015). On the contrary, there is no clear evidence of expanding farmland or new irrigation techniques in north-western Arabia, as if the oasis had "absorbed" the innovation with limited social and economic impacts.

\section{The Ginning Process: Household or Handcraft Activity?}

The presence of whole and broken seed remains in substantial quantities at several archaeological sites indicates that the first step of textile production-removing the seeds from the lint, or ginning - occurred locally. However, the seeds do not have the same meaning whether they are charred or desiccated and according to the archaeological context in which they were found.

\section{Routes of Entry into Archaeobotanical Assemblages}

The assessment of the formation processes of desiccated and charred cotton seeds aims to determine the various routes of entry into the archaeobotanical record, which may illustrate day-to-day routine behavioural practices (Van der Veen 2007). The first and most basic interpretation is to assume that after ginning, the seeds were directly thrown away in dumps (desiccated seeds) or fireplaces (charred seeds) (Fig. 6). In both cases, the fragmentation of the seed coat might result from the use of a ginning roller, from trampling after dumping (desiccated seeds) and/or from breaking during charring (charred seeds). Nevertheless, it is highly conceivable that people, most of all in an environment characterized by limited natural resources, tried to recycle waste derived from the various cotton processing steps, as they do with other agricultural by-products ${ }^{3}$ (Anderson and Ertuğ-Yaras 1998; Van der Veen 1999; Bouchaud et al. 2012). Stems, leaves, roots, capsules and oil-rich seeds of cotton naturally secrete a toxic compound known as gossypol, which make them inedible for humans or non-ruminant animals. To our knowledge, no mechanical or non-chemical process to eliminate this toxic compound existed before the $20^{\text {th }}$ century (Trolinder 2009), so we must assume that cotton by-products were likely useless in the past for cooking or feeding non-ruminant animals. Nevertheless, leaves, immature capsules and dry pericarps present in the field after the harvest, as well as seeds or pressed seed-cakes resulting from the ginning process might have been consumed by ruminants as they are in present-day small farms in Africa and India (Suttie 2004). Sheep and goat are most resistant to toxicity but small and occasional quantities seem to have no effect on cattle (Suttie 2004) and camel (Omer et al. 2008). However, no clear remains of cotton seeds have been found to date in sheep/goat dung pellets, except at Afyeh (Chowdhury and Buth 1971). Apart from the food, daily domestic oil needs in the past were much higher than today because of its use for lighting (Copley et al. 2005; Bonnéric 2012). Ancient

\footnotetext{
${ }^{3}$ In this light, the absence of cotton wood among the anthracological assemblage is quite surprising, most of all if ancient cotton was perennial, and deserves further investigation.
} 
people must have noticed the rich-oil content of the cotton seed and it would be worthwhile to consider that cotton oil was used in lamps. To date, only one reference, from the Babylonian Talmud compiled around $500 \mathrm{AD}$, suggests that cotton seed oil was used, without specification, by the Jewish communities of Persian Mesopotamia (see comment in Newman 1932; Decker 2009). Ethnographic data of the middle of the $20^{\text {th }}$ century in Anatolia show that cotton oil was obtained from roasted, ground and pressed seeds (Wulff 1966; Ertuğ 2000). These processes, as well as pressing activities during ginning and the use of dung from animals having ingested seeds or seed-cakes might therefore also explain the presence of fragmented seeds in the archaeobotanical assemblages. Finally, leaves, flowers, seeds and roots were still recently used in Ethiopia for medicinal purposes (Nicholson 1960:15). According to Prospero Alpini, Egyptian people of the $16^{\text {th }}$ century used the mucilage from the seed to ease fever, stomach pain and cough (Prospero Alpini, De Plantis Aegypti liber XVIII, De Fenoyl 2007). These medicinal uses likely imply special processes that might have led the cotton waste to be deposited and preserved through time.

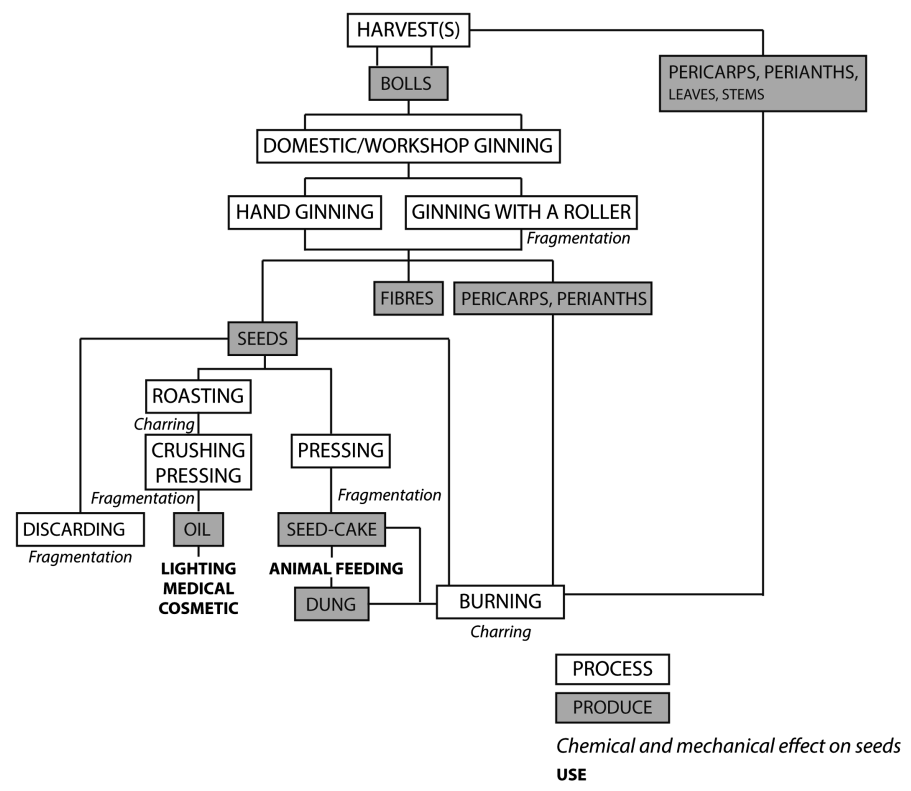

Fig. 6. Detailed diagram of the potential use of cotton seeds andvarious routes of entry into the archaeobotanical record.

Considering these different options ${ }^{4}$, several paths of entry may explain the presence of desiccated and charred, fragmented and whole cotton remains in archaeological contexts (Fig. 6). All archaeobotanical assemblages presented in this paper include

\footnotetext{
${ }^{4}$ Accidental fires might also explain the presence of charred cotton items, but no traces of such events have been clearly recorded.
} 
whole and fragmented cotton seeds. On Egyptian sites where climatic conditions allow the preservation of organic material (Qasr Ibrim, Kellis, Amheida), both charred and desiccated cotton items are present that suggest different routes of entry and their potential uses before being discarded. Otherwise, the proportion of fragmented charred seeds versus whole seeds is much lower at Madâ'in Sâlih than, for instance, at Muweis. If in the first case, a low rate of fragmentation cannot be used as indicator of any activities, we would suggest as a working hypothesis for future investigations that a high rate of fragmentation, as seen at Muweis or Qasr Ibrim, results from the use of the seeds before discarding.

\section{Domestic Routine Versus Handcraft Specialisation}

The presence of cotton bolls, seeds and raw fibres, despite indicating that the ginning process was taking place locally, does not necessarily mean that the site was a centre of agricultural production. Indeed, ginning occurred either within the domestic sphere, where the cotton bolls directly came from one or several local harvest, or in specialised workshops where the product of several harvests from different local/regional places might have been centralised.

Spatial and contextual criteria can provide important clues to reconstruct the organisation and management of the product and to distinguish domestic from handcraft contexts. For the majority of the sites, such as Madâ'in Sâlih, Kellis and Trimithis, cotton waste has been found in dumps and fireplaces, mixed with other food and fuel wastes, irregularly distributed in several household contexts. The domestic context is here quite clear, and it is reasonable to conclude that cotton bolls directly came from the neighbouring fields and were processed within small units of habitation, beside other domestic activities as food preparation, probably to meet the family's basic needs. It has been suggested that the fort of Qasr Ibrim would represent, at least during Meroitic and post-Meroitic periods, a craft workshop (Adams 2013) for which cotton harvests from local or regional fields would have been centralised. However, there is no evidence of storage areas on the site at that time to support this hypothesis and, despite of the density of textile tools on the site pointing to the importance of spinning and weaving activities, it is more likely that collection and processing of cotton took place at a domestic or individual household level. In some cases, especially at Kellis during the $4^{\text {th }}$ century, the density of cotton remains (Thanheiser 2002), the presence of textiles and tools (Bowen 2001, 2010) and a written mention (KAB 558; Bagnall 1997) attest to a small textile and tailoring workshop organised by a woman, which provides evidence that such goods could be sold locally (Bowen 2001, 2010; Boozer 2015b).

\section{The African Cotton}

In 1960, G. E. Nicholson wrote: "The precise region of Africa where the cultivated Old World cottons first arose is still a matter of much conjecture" (Nicholson 1960:26). More than fifty years later, this issue can now be analysed in the light of new data regarding the role and diffusion of the African cotton species, Gossypium herbaceum. 


\section{Area of Domestication and Spread}

An archaeogenomic study performed on $4^{\text {th }}$ century AD cotton seeds from Qasr Ibrim has demonstrated that African cotton, G. herbaceum, was present in Nubia and cultivated during Antiquity (Palmer et al. 2012). This result corroborates an older hypothesis based on the analyses of Nubian textiles (Griffith and Crowfoot 1934) and refutes the theory that the rise of cotton production in north-eastern Africa was the result of imported $G$. arboreum from India (Watson 1983:34). Based on this archaeogenomic result, as well as the growing record of cotton archaeobotanical remains in Nubia and Central Sudan, and the Meroitic creation of a characteristic textile style (Yvanez 2015), it is tempting to assume that $G$. herbaceum had been consistently used since the beginning of the Nubian and Sudanese cotton production.

Even so, this assumption does not directly address the issue of where and when $G$. herbaceum was domesticated. According to the latest phylogenetic research, cultivated $G$. herbaceum was derived from a truly wild diploid ancestor, G. herbaceum var. africanum, which is the only wild taxon in the genus that bears lint. Today, this subspecies grows naturally in southern Africa, more specifically in Namibia, Botswana, South Africa, Zimbabwe and Mozambique (Hutchinson 1959; Vollesen 1987:345; Kulkarni et al. 2009:71). Hypotheses regarding its geographical origin first placed the centre of domestication in these southern regions (Hutchinson 1959). Others, following the idea of a northward migration of the wild form from southern Africa and loss of photoperiodism, postulate that domestication took place in southern Arabia (Kulkarni et al. 2009) or Ethiopia (Nicholson 1960; Kulkarni et al. 2009), where the most primitive perennial cultivar, G. herbaceum race "acerifolium," is observed (Kulkarni et al. 2009). The southern Africa and southern Arabia hypotheses are quite difficult to evaluate as no other reliable evidence has emerged t to date and neither archaeobotanical data nor written sources attest to the existence of cotton before the Medieval period in both areas (Davison and Harries (1980) for South-East Africa; Varisco (2009) for Yemen). Of much interest is the eastern Africa hypothesis, because it puts the already demonstrated spread of cotton in Central Sudan and Nubia in the immediate wake of this process.

The arguments put forward for a domestication in East Africa are based on botanical observations made in the mid- $20^{\text {th }}$ century, showing that despite the low number of populations and varieties analysed, the phenotypic and ecological variability within the cultivar G. herbaceum race 'acerifolium' is quite high, especially in southern Ethiopia (Nicholson 1960:24). Furthermore, at least four species of wild perennial Gossypium have been collected and recorded in the region. G. anomalum Wawr. \& Peyer. has been observed near the Sudan-Eritreaa border, G. anomalum Wawr. Ex Wawr. \& Peyer. subsp. senarense (Fenzl ex Wawr \& Peyer.) Vollesen in the wet bushland and grassland of western and central Sudan and G. bricchettii (Ulbr.) Vollesen among the Acacia-Commiphora woodland and bushland proper formation in eastern Ethiopia (Friis et al. 2011:54; Darbyshire et al. 2015:250). Gossypiumsomalense (Gürke) J. B. Hutch. has been recorded in all these places as well (Nicholson 1960:25; Obeid and Mahmoud 1971:190; Darbyshire et al. 2015:251). Finally, G. longicalyx Hutch. and B. J. S. Lee, which is thought to represent the wild form most closely related to the A-genome species (Wendel et al. 2009:13), is also present in East 
Africa - in South Sudan, Ethiopia and Tanzania (Vollesen 1987:346; Wendel et al. 2009:6; Darbyshire et al. 2015:251). Although this relatively high number of wild relatives cannot be directly correlated to a centre of domestication, it highlights a rich germplasm diversity. In addition, multiplicity in cultivars is also expressed through the distinctive vernacular names for cotton in Ethiopia and most of all in the old Hamitic languages (see the linguistic analyses reported in Nicholson (1960:23). This wild and domestic diversity would explain the absence of the known wild ancestor G. herbaceum var. africanum in the region. Indeed, the ease with which intercrossing can occur in cotton suggests that in areas where cotton was domesticated or diversified, the wild ancestor of the cultivated plant may have disappeared as it evolved in association with cultivars (Watson 1983:32; Wendel et al. 2009:7).

One can postulate that the domestication process occurred somewhere in the eastern part of the sub-Saharan humid savannahs. Unfortunately, the absence of recent genetic analyses, the humid climatic conditions that led to the very poor preservation of organic material, as well as the lack of archaeological studies and written sources from those regions, restrict the possibility to verify the reliability of this option. The only historical data recovered to date consist of late records. First, the mention of cotton in the Ezana inscription (see above) shows that in the $4^{\text {th }}$ century AD, the plant was known and had a specific local name in the Ge'ez language, $t \bar{u} t$, and is still used in Amharic (Littmann (1913), see comment in Zeitschrift der Deutschen Morgenländischen Gesellschaft 67:701). Secondly, five textile pieces found at Kidane Mehret in northern Ethiopia (Phillipson 2012:179) and a few charred seeds coming from a domestic context at Aksum (Boardman 1999; Phillipson 2000) demonstrate the presence of cotton in Ethiopia during the $6^{\text {th }}-7^{\text {th }}$ centuries AD. Likewise, the southern regions of present Sudan and South Sudan, which could link the archaeological records of Nubia and central Sudan to the potential location of $G$. herbaceum domestication, is almost devoid of data. No textile or seeds have survived in the very limited archaeological record of these humid regions. Nonetheless, the many spindle whorls found at Abu Geili, a Late Meroitic site located on the eastern shore of the Blue Nile in the Gezira area, suggest the spinning of short fibres in significant quantities, which could be wool, or, because of the regional context, most probably cotton (Yvanez 2016). While awaiting further analyses and new tools to better understand the emergence of cotton in Africa, the available data lead us to consider the Meroitic territory as an important centre of spread for the species $G$. herbaceum, whose roots may be sought in the southern humid savannahs of eastern Africa.

\section{Trade as a Stimulus for Local Production}

Cotton history is a reliable example of the process described by A. Sherratt who argues that trade in consumables is one way in which crops, particularly non-staple crops, spread beyond their core areas of domestication (Sherratt 1999). Based on the spatial and chronological distribution of the available data in Africa, we postulate that the trade of Indian cotton, G. arboreum, passing through various localities in the Indian Ocean, 
stimulated local production and played an indirect role in the spread, if not the domestication, of $G$. herbaceum in sub-Saharan Africa.

This argument first relies on the Periplus Maris Erythreae (PME). This text, which describes the movement of Eastern luxuries to the ports of Egypt and the Red Sea trade, also reports a second line of trade revealed by the detailed examination of the imports and their sources that the author lists for the various ports. This concerns the trade of textiles, foods and raw materials from India to the coasts of Persia, southern Arabia and East Africa handled by Arabs or Indians, in which the merchants of Roman Egypt had no or very little part in (Casson 1989:21). More specifically, the PME reports that Indian cotton cloth went to southern Arabia (Moscha Limên [PME 32:11.3]), northern Somalia ("far-side" ports [PME 14:5.10-13]) and the Ethiopian coast (Adulis [PME 6:3.1-3]). According to the description, most of the cotton cloth exported to Adulis and northern Somalia was of cheap quality and it is assumed that it was probably the same for the cotton cloth exported to southern Arabia. The finer cotton cloth and garments exported to Adulis [PME 6:3.3] are interpreted as higher-value items intended for the foreign colony residing there [PME 6:2.32] (Casson 1989:19). To date, there is very little archaeological evidence directly arising from the mentioned ports, making it impossible to demonstrate the link between these records of cheap and fine cotton imports and the emergence of a local production. Nevertheless, it is interesting to note that the earliest known production centres in western Arabia and north-eastern Africa appeared in Nabataean and Meroitic societies: both settled inland territories, engaged in overland caravan trade, and acting as intermediaries to supply certain goods to the Mediterranean world or to the ports of eastern and southern Arabia and the Horn of Africa (for the Nabataeans, Durand 2009; Terpstra 2015; for the Meroitics, Haaland 2014). The conjunction of well-established states where agriculture and trade activities are both developed and the existence of long-distance trade dynamics could have created a positive global context not only for the exchange of goods, but also for the acquisition of agricultural and economic novelties by Arab and African societies. The question remain open if the domestication and diffusion of African cotton is correlatedwith the circulation of the already known cotton from India in the various trade networks. We might suggest that the circulation of cotton cloth and garments led Meroitic inhabitants to use a similar resource growing locally, i.e.G. herbaceum, and the Nabataeans to adopt a new plant, but this is purely speculative. However, according to this point of view and the fact that exchanges existed between India, Arabia and Africa, we must consider that the cotton cultivated in north-western Arabia could be $G$. arboreum as much as G. herbaceum (Bouchaud 2015).

In conclusion, it is important to remember that the spread of local production centres did not prevent Indian cotton from being imported and maintaining a prominent status through time. This is well demonstrated by the Indian items discovered in several Egyptian sites during the $1^{\text {st }}-4^{\text {th }}$ centuries, such as in Berenike or Kellis (Bender Jørgensen and Vogelsang-Eastwood 1991; Livingstone 2009; Wild and Wild 2014a, c), as well as the European evidence throughout Medieval (Mazzaoui 1981) and Modern times (Riello and Roy 2009). 


\section{Conclusion}

This overview of the history of cotton in western Arabia and north-eastern Africa highlights the benefits of an interdisciplinary approach while underlining the extreme difficulty to perceive the chronological, biological, economic and sociological details of change. These limits result mainly from methodological aspects caused first by a lack of data and secondly by botanical characterisation issues. Regarding the first challenge, it is worth mentioning that the available documentation on northeast Africa and Arabia is rapidly growing, as many recent excavations conducted on Antique sites that included archaeobotanical studies have yielded new occurrences of cotton remains. Regarding the second issue, our efforts should now concentrate on the development of techniques to better identify archaeobotanical and textile remains of cotton. Increasing the number and the quality of specimens will most probably improve our understanding of the spatio-temporality of the diffusion of cotton. For now, the evidence demonstrates that cotton cultivation spread on both sides of the Red Sea around the end of the $1^{\text {st }}$ millennium BC-beginning of the $1^{\text {st }}$ millennium AD onwards, and that its dispersal out of its tropical region of origin demonstrates the agricultural skills of the societies that adopted it. In these regions, a key aspect of cotton production was its addition to pre-existing textile traditions dominated by flax and wool, rather than its introduction into areas devoid of textile plant resources. Another important aspect to consider is that, as far as we can see, the first attempts were not directly linked to new irrigation practices, which occurred earlier (in Egyptian oases) or later (in Nubia). It means that people introduced cotton by using existing technical knowledge of irrigation and perhaps developed alternative and original strategies in response. This leads us to consider a "bottom up" perspective (Thurston and Fisher 2007) according to which these first attempts were probably based on experimentations handled by local farmers rather than an institution. Later, the development of cotton production as observed in the Meroitic kingdom might have concurred with a progressive controlling of the product and its transformation bygoverning bodies, leading to an increase of production and the potential development of trade, at least during the Late Meroitic and post-Meroitic periods (Fuller 2014). In this way, Meroitic sub-Saharan cotton trade may have played a significant role in the emergence of local cotton production in the Egyptian western oases and Libyan oases during the $2^{\text {nd }}-3^{\text {rd }}$ centuries AD (Clapham and Rowley-Conwy 2009; Tallet et al. 2012).

At this stage of our knowledge, it is not possible e to precisely identify where and when the two Old World cotton species were first in use: probably during the $6^{\text {th }}-5^{\text {th }}$ millennia $\mathrm{BC}$ in northern India, and somewhere in tropical Africa at the end of the $1^{\text {st }}$ millennium $\mathrm{BC}$ at the latest. Nevertheless, more e data coming from Arabia and north-eastern Africa marks the turn of the $1^{\text {st }}$ millennium $\mathrm{BC}$ with the beginning of the $1^{\text {st }}$ millennium $\mathrm{AD}$ as a key moment in cotton history, embodied by the formidable expansion of both $G$. herbaceum and G. arboreum utilisation.

Acknowledgements. We thank the members of the Fyssen Foundation for awarding the Grant Research (2016-2017) that supported this study.

Charlène Bouchaud and Claire Newton are grateful to Marie Millet for inviting them to participate in the French archaeological mission at Mouweis, making available the unpublished 
radiocarbon dates and for her comments on this paper. Charlène Bouchaud also warmly thank Daifallah al-Talhi, Laïla Nehmé and François Villeneuve for having entrusted her with the analysis of the plant remains from Madâ'in Sâlih.

Alan Clapham would like to thank Dr Pamela Rose of the Österriechisches Archälogisches Institut Zweigstelle Kairo for the opportunity to work on the plant remains from Hisn al Bab, Aswan, Egypt and The Egyptian Exploration Society and Dr Pamela Rose for the chance to work on the material from Qasr Ibrim.

We also thank the two anonymous reviewers for their valuable comments on the first draft of this paper, as well as Anna Maria Mercuri and the IWAA8 team for the organisation of the conference in Modena.

\section{References}

Abasaeed AE (1992) Briquetting of carbonized cotton stalk. Energy 17(9):877-882

Adams NK (2007) Political affinities and economic fluctuations: the evidence from the textiles at Qasr Ibrim. In: Godlewski W, Lajtar A (eds) Between the cataracts, Part 2, fascicule 1. Warsaw University Press, Warsaw

Adams WY (2013) Qasr Ibrim: ballana phase (EES excavation memoir 104). Egypt Exploration Society, London

Adams WY, Adams NK, van Gerven DP et al (1999) Kulubnarti III: the cemeteries (BAR S814). Archaeopress, Oxford

Agut-Labordère D, Newton C (2013) L'économie végétale à 'Ayn-Manâwir à l'époque perse: archéobotanique et sources démotiques, Achaemenid research on texts and archaeology 2013.005. http://www.achemenet.com/en/table/?/on-line-publications/arta/tableau-des-articles . Accessed 26 May 2017

Anderson RD, Adams WY (1979) Qaṣr Ibrîm 1978. J Egypt Archaeol 65:30-41

Anderson S, Ertuğ-Yaras F (1998) Fuel fodder and faeces: an ethnographic and botanical study of dung fuel use in central Anatolia. In: Charles M, Halstead P, Glynis J (eds) Fodder: archaeological, historical and ethnographic studies (environmental archaeology). Oxbow Books, Oxford, pp 99-109

Aubaile-Sallenave F (1984) L'agriculture musulmane aux premiers temps de la conquête: apports et emprunts. J Agriculture Traditionnelle et de Botanique Appliquée 31(3-4):245-256

Bagnall RS (1997) The Kellis agricultural account book (Dakhleh Oasis Project). Oxbow Books, Oxford

Bagnall RS (2008) SB 6.9025, cotton, and the economy of the small oasis. B Am Soc Papyrologis 45:21-30

Bagnall RS, Cribiore R (2006) Women's letters from ancient Egypt, 300 BC-AD 800. University of Michigan Press, Ann Arbor

Bagnall RS, Ruffini G (2012) Amheida I: Ostraka from Trimithis, vol 1. New York University Press/Institute for the Study of the Ancient World, New York

Barber EJW (1993) Prehistoric textiles: the development of cloth in the neolithic and bronze ages with special reference to the Aegean. Princeton University Press, Princeton

Baud M (2010a) Mouweis, une ville type de la vallée? In Méroé: un empire sur le Nil. Musée du Louvre. Officina libraria, Paris, Milan, pp. 216-219

Baud M (2010b) Méroé: un empire sur le Nil. Musée du Louvre. Officina libraria, Paris, Milan Baud M (2014) Downtown Muweis - a progress report (2007-2011). In: Welsby D, Anderson JR (eds) The fourth cataract and beyond. Proceedings of the 12th international conference for Nubian studies. Walpole, Paris 
Bellinger L (1962) Textiles. In: Colt HD (ed) Excavations at nessana 1. Princeton University Press, Princeton, pp 91-105

Bender Jørgensen L (2004) A matter of material: changes in textiles from roman sites in Egypt's eastern desert. Antiquité Tardive 12(1):87-99

Bender Jørgensen L (2006) The late roman fort at 'Abu Sha'ar, Egypt: textiles in their archaeological context. Riggisberger Berichte 13:161-173

Bender Jørgensen L, Vogelsang-Eastwood GM (1991) The Abu Sha'ar textiles 1991. Archaeological Textiles Newsl 13:3-4

Benedict CR, Kohel RJ, Lewis HL (1999) Cotton fiber quality. In: Smith CW, Cothren JT (eds) Cotton: origin, history, technology and production. Wiley, New York, pp 269-288

Betts A, van der Borg K, de Jong A et al (1994) Early cotton in North Arabia. J Archaeol Sci 21 (4):489-499

Boardman S (1999) The agricultural foundation of the Aksumite Empire, Ethiopia: an interim report. In: Van der Veen M (ed) The exploitation of plant resources in ancient Africa. Kluwer Academic, New York, pp 137-147

Boivin N, Fuller DQ (2009) Shell middens, ships and seeds: exploring coastal subsistence, maritime trade and dispersal of domesticates in and around the ancient Arabian Peninsula. J World Prehist 22:113-180

Bond WRG (1925) Some curious methods of cultivation in Dongola Province. Sudan Notes Records 8:97-103

Bonnéric J (2012) Les huiles et leurs usages en terre d'Islam à partir du VIIe s. In: D Frère, L Hugot (eds) Les Huiles Parfumées En Méditerranée Occidentale et En Gaule (VIIIe Av.VIIIe Ap. J.-C.) (Archéologie de l'artisanat antique 6). Centre Jean Bérard, Presses Universitaires de Rennes, Rennes, pp. 307-314

Boozer AL (2015a) Domestic archaeology and the Romano-Egyptian house. An integrated research agenda. In: AL Boozer (ed) Amheida II: a late Romano-Egyptian house in the Dakhleh Oasis. Amheida House B2. The Institute for the study of the Ancient world, New York

Boozer AL (2015b) Woven material. In: AL Boozer (ed) Amheida House B2 Amheida II: a late Romano-Egyptian house in the Dakhleh Oasis. The Institute for the study of the Ancient world, New York

Bouchaud C (2015) Agrarian legacies and innovations in the Nabataean territory. ArchéoSciences 39:103-124

Bouchaud C, Sachet I, Dal-Prà P et al (2015) New discoveries in a Nabataean tomb. Burial practices and 'plant jewellery' in ancient Hegra (Madâ'in Sâlih, Saudi Arabia). Arab Archaeol Epigr 26:28-42

Bouchaud C, Tengberg M, Dal Prà $\mathrm{P}$ (2011) Cotton cultivation and textile production in the Arabian Peninsula during antiquity: the evidence from Madâ'in Sâlih (Saudi Arabia) and Qal'at al-Bahrain (Bahrain). Veg Hist Archaeobot 20:405-417

Bouchaud C, Thomas R, Tengberg M (2012) Optimal use of the date palm (Phoenix dactylifera L.) during Antiquity: Anatomical identification of plant remains from Madâ'in Sâlih (Saudi Arabia). In: Badal E (ed) Wood and Charcoal. Evidences for the Human and Natural History. (Saguntum-Extra 13). Universitat de Valencia, Valencia, pp. 173-185

Boulos L (2000) Flora of Egypt. Volume 2 (Geraniaceae-Boraginaceae). Al Hadara, Cairo

Bowen G (2010) Texts and textiles: a study of the textile industry at ancient Kellis. http:// artsonline.monash.edu.au/ancient-cultures/texts-and-textiles-a-study-of-the-textile-industryat-ancient-kellis/. Accessed 3 Feb 2017

Bowen GE (2001) Texts and textiles: a study of the textile industry at ancient Kellis. Artifact 24:18-28 
Bravard J-P, Mostafa A, Garcier R et al (2016) Rise and fall of an Egyptian Oasis: artesian flow, irrigation soils, and historical agricultural development in El-Deir, Kharga Depression. Western Desert Egypt. Geoarchaeol 31(6):467-486

Brite EB, Marston JM (2013) Environmental change, agricultural innovation, and the spread of cotton agriculture in the Old World. J Anthropol Archaeol 32(1):39-53

Brookfield HC (1984) Intensification revisited. Pac Viewpoint 25(1):15-44

Brubaker CL, Bourland FM, Wendel JF (1999) The origin and domestication of cotton. In: Smith CW, Cothren JT (eds) Cotton: origin, history, technology and production. Wiley, New York, pp 3-31

Bulliet RW (2009) Cotton, climate, and camels in early Islamic Iran. Columbia University Press, New York

Casson L (1989) The periplus maris erythraei. University Press, Princeton

Chaudhry RM, Guitchounts A (2003) Cotton facts. Cotton Advisory Committee, Washington

Chauveau M (2005) Irrigation et exploitation de la terre dans l'oasis de Kharga à l'époque perse. Cahier de recherches de l'Institut de papyrologie et d'égyptologie de Lille 25:157-163

Chowdhury KA, Buth GM (1971) Cotton seeds from the neolithic in Egyptian Nubia and the origin of Old World cotton. Biol J Linn Soc 3(4):303-312

Clapham A, Rowley-Conwy P (2007) New discoveries at Qasr Ibrim, Lower Nubia, in Fields of Change. In: Cappers RTJ (ed) Proceedings of the 4th international workshop for African archaeobotany (Groningen archaeological studies 5). Barkhuis and Groningen University Library, Groningen, 157-164

Clapham A, Rowley-Conwy P (2009) The archaeobotany of cotton (Gossypium sp. L.) in Egypt and Nubia with special reference to Qasr Ibrim, Egyptian Nubia. In: From Foragers to farmers. Papers in Honour of Gordon C Hillman, A Fairbairn, E Weiss (eds) Oxbow Books, Oxford, pp. 244-253

Coombs CE, Woodhead AL, Church JS (2002) Report on the characterization of three fabric samples from Ismant el-Kharab. In: Hope CA, Bowen GE (eds) Dakhleh Oasis project: preliminary reports on the 1994-1995 to 1998-1999 field seasons. Oxbow Books, Oxford, pp 115-119

Copley MS, Bland HA, Rose P et al (2005) Gas chromatographic, mass spectrometric and stable carbon isotopic investigations of organic residues of plant oils and animal fats employed as illuminants in archaeological lamps from Egypt. Analyst 130(6):860-871

Courbon P (2008) Les puits nabatéens de Madâ' in Sâlih (Arabie Saoudite). Arab Archaeol Epigr 19(1):48-70

Crowfoot GM (1924) The handspinning of cotton in the Sudan. Sudan Notes Records 7(2):83

Crowfoot GM (1931) Methods of hand spinning in Egypt and the Sudan (Bankfield Museum Notes 12). F King \& Sons, Halifax

Cuvigny H, Wagner G (1986) Les Ostraca Grecs de Douch: (O. Douch). Fascicule I. 1-57 (Document de fouilles 24). Institut Français d'Archéologie Orientale, Cairo

Darbyshire I, Kordofani M, Farag I et al (eds) (2015) The plants of Sudan and South Sudan: an annotated checklist. Royal botanic gardens. Kew publishing, Kew

Davison P, Harries P (1980) Cotton weaving in South-East Africa: its history and technology. Text Hist 11(1):175-192

De Fenoyl R (ed) (2007) Plantes d'Egypte, Par Prosper Alpin, 1581-1584 (Voyageurs 22). Institut Français d'Archéologie Orientale, Cairo

De Fenoyl R, Sauneron S (eds.) (2007) Histoire Naturelle de l'Egypte, Par Prosper Alpin, 15811584, Vol. I et II (Voyageurs 20). Institut Français d'Archéologie Orientale, Cairo

Decker M (2009) Plants and progress: rethinking the Islamic agricultural revolution. J World Hist 20(2):187-206 
Dillehay TD, Rossen J, Andres TC et al (2007) Preceramic adoption of peanut, squash, and cotton in Northern Peru. Science 316(5833):1890-1893

Dunand F, Heim J-L, Henein N et al (1992) La nécropole de douch. Douch I. Institut Français d'Archéologie Orientale, Cairo

Dunham D (1963) The royal cemeteries of Kush, Volume V: The West and South Cemeteries at Meroë. Museum of Fine Arts, Boston

Durand C (2009) The Nabataeans and oriental trade: roads and commodities (Fourth Century BC to the First Century AD). Stud Hist Archaeol Jordan 10(405):12

Durand C, Gerber Y (2014) The pottery production from Hegra/Madâ'in Sâlih (Saudi Arabia) during the Nabataean period. Preliminary results, 2008-2011. Proc Sem Arab Stud 44:153167

Edwards DN (1996) The archaeology of the Meroitic state: new perspectives on its social and political organisation (Cambridge monographs in African archaeology 38). Tempus Reparatum, Oxford

Edwards DN (2004) The Nubian past. An archaeology of the Sudan. Londres, Routledge, New York

El Faïz M (2000) Le Livre de L'agriculture d'Ibn Al-'Auwām (Kitāb Al-Filāḥa). Actes sud, Sindbad, Paris

Ertuğ F (2000) Linseed oil and oil mills in central Turkey Flax/Linum and Eruca, important oil plants of Anatolia. Anatol Stud 50:171-185

Eyhorn F, Ratter SG, Ramakrishnan M (2005) Organic cotton crop guide. A manual for practitioners in the tropics. Research Institute of Organic Agriculture (FIBL), Frick

Friis I, Demissew S, van Breugel P (2011) Atlas of the potential vegetation of Ethiopia. Addis Ababa University Press \& Shama Books, Addis Ababa

Fuller DQ (2008) The spread of textile production and textile crops in India beyond the Harappan zone: an aspect of the emergence of craft specialization and systematic trade, Linguistics, archaeology and the human past. Indus Project. Research Institute for Humanity and Nature, Kyoto, pp. 1-26

Fuller DQ (2014) Agriculture innovation and state collapse in Meroitic Nubia. In: Stevens CJ, Nixon S, Murray MA, Fuller DQ (eds) Archaeology of African plant use. Left Coast Press, Walnut Creek, pp 165-177

Fuller DQ (2015) The economic basis of the Qustul splinter state: cash crops, subsistence shifts, and labour demands in the post-meroitic transition. In: Zach M (ed) Proceedings of the 11th international conference for meroitic studies (Beitrage zur Sudanforschung Beiheft series) Kushite World. Verein der Förderer der Sudanforschung, Vienna, pp. 33-60

Fuller DQ, Edwards DN (2001) Medieval plant economy in middle Nubia: preliminary archaeobotanical evidence from Nauri. Sudan Nubia Bull 5:97-103

Fuller DQ, Pelling P, De Varailles A (Forthcoming) Staple grains, crops and social differentiation: archaeobotanical studies at Volubilis, Marocco. In: Fentress E, Limane H (eds) Excavations at volubilis, Marocco

Gardner I, Alcock A, Funk W-P (eds) (1999) Coptic documentary texts from Kellis, vol 1. Oxbow Books, Oxford P. Kell V

Gleba M, Mannering U (eds) (2012) Textiles and textile production in Europe from prehistory to AD 400 (Ancient textiles series 11). Oxbow Books, Oxford

Gomes RS, Wilson PN, Coates WE et al (1997) Cotton (Gossypium) plant residue for industrial fuel: an economic assessment. Ind Crop Prod 7(1):1-8 
Gonon T, Thiers C, Wuttmann M (2005) Les qanâts d'Ayn Manawir (Oasis de Kharga, Égypte): techniques de creusement et dynamique de l'exploitation d'une ressource épuisable, de la Première Domination Perse au IIe siècle de l'ère commune. Internationales Frontinus-Symposium « Wasserversorgung Aus Qanaten-Qanate Als Vorbilder Im Tunnelbau. Frontinus Gesellschaft, Bonn, pp 39-57

Granger-Taylor H (2000) The textiles from Khirbet Qazone (Jordan). In: Cardon D, Feugère M (eds) Archéologie des textiles, des origines au ve siècle. Actes Du Colloque de Lattes, Octobre 1999. Monique Mergoil, Montagnac, pp. 149-161

Granger-Taylor H (2007) Textiles of the Herodian, Nabataean and Roman periods from the Dead Sea area. In: Politis KD (ed) The world of the Nabataeans. Steiner-Verlag, Stuttgart, pp 301307

Griffith FL, Crowfoot GM (1934) On the early use of cotton in the Nile valley. J Egypt Archaeol 20(1/2):5-12

Haaland R (2014) The meroitic empire: trade and cultural influences in an Indian Ocean context. Afr Archaeol Rev 31(4):649-673

Handley FJL (2004) Quseir al-Qadim 2003: the textiles. Text News1 38:27-30

Hutchinson J (1959) The application of genetics to cotton improvement. Cambridge University Press, Cambridge

Jones J, Oldfield R (2006) A Kind of Wool is made by the Egyptians from a Tree. Archaeol Text Newsl 43:27-32

Kirch PV (1994) The wet and the dry: irrigation and agricultural intensification in Polynesia. University of Chicago Press, Chicago

Kulkarni VN, Khadi BM, Maralappanavar MS et al (2009) The worldwide gene pools of Gossypium arboreum L. and G. herbaceum L., and their improvement. In: Paterson AH (ed.) Genetics and genomics of cotton, (Plant Genetics and Genomics: Crops and Models 3). Springer US, New York, pp. 69-97

Leroi-Gourhan A (1971) L'homme et la matière. Albin Michel, Paris

Letellier-Willemin F, Médard F (2012) Techniques inattendues dans un fragment textile en coton, du site d'El Deir, Oasis de Kharga. Désert Ocidental Égyptien, Archaeol Text Rev, p 54

Letellier-Willemin F, Moulhérat C (2006) La découverte de coton, oasis de Kharga. Archaeol Text Newsl 43:20-27

Littmann E (1913) Deutsche Aksum-Expedition. Bd IV. Sabaische, Griechische Und Altabessinische Inschriften. Museum of Berlin, Berlin

Livingstone R (2009) Late antique household textiles from the village of kellis in the dakhleh oasis. In: De Moor A, Fluck C (eds) Clothing the house: furnishing textiles of the 1st millennium from Egypt and neighbouring countries. Lannoo, Tielt, pp 73-85

Livingstone RJ (2015) Dress and identity in Kellis, a Roman-period village in Egypt, thesis, Monash University. Faculty of Arts. Centre for Ancient Cultures, School of Philosphical, Historical and International Studies

Lombard M (2002) Les textiles dans le monde musulman du VIIe au XIIe siècle. École des Hautes Etudes en Sciences Sociales, Paris

Massey RE (1923) A note on the early history of cotton. Sudan Notes Rec 6(2):231

Mayer-Thurman CC, Williams B (1979) Ancient textiles from nubia: meroitic, x-group, and Christian fabrics from Ballana and Qustul. Art Institute of Chicago, Chicago

Mazzaoui MF (1981) The Italian cotton industry in the later middle ages, 1100-1600. Cambridge University Press, Cambridge

Miller NF (1998) Patterns of agriculture and land use at medieval gritille. In: Redford S (ed) Archaeology of the frontier in the medieval near East (Archaeological Institute of America Monographs 3). University of Pennsylvania Museum, Philadelphia, pp 211-252 
Miller NF (2010) Botanical aspects of environment and economy at Gordion. University of Pennsylvania Museum of Archaeology and Anthropology, Philadelphia, Turkey

Millet M (2013) Mouweis: une ville de l'empire de Méroé. Bulletin de la Société Française d'Egyptologie 186-187:83-98

Morrison KD, Feinman GM, Nicholas LM et al (1996) Typological schemes and agricultural change: beyond boserup in precolonial South India [and comments and reply]. Curr Anthropol 37(4):583-608

Moulhérat C, Tengberg M, Haquet JF (2002) First evidence of cotton at Neolithic Mehrgarh, Pakistan: analysis of mineralized fibres from a copper bead. J Archaeol Sci 29(12):1393-1401

Müller M, Murphy B, Burghammer M et al (2004) Identification of ancient textile fibres from Khirbet Qumran caves using synchrotron radiation microbeam diffraction. Spectrochim Acta B 59(10):1669-1674

Müller M, Papiz MZ, Clarke DT et al (2003) Identification of the textiles from Khirbet Qumran using microscopy and synchrotron radiation $\mathrm{x}$-ray fibre diffraction. In: Humbert J-B, Gunneweg J (eds) Khirbet Qumrân et'Aïn Feshkha II. Studies of Anthropology, Physics and Chemistry. Academic Press, Vandenhoeck \& Ruprecht, Fribourg, pp. 277-286

Murray A, Cappers RTJ (2007) Medieval cotton and wheat finds in the Middle Niger Delta (Mali). In: Fields of Change. Proceedings of the 4th international workshop for African archaeobotany (Groningen archaeological studies 5). Barkhuis \& Groningen University Library, Groningen, pp. 43-51

Murray MA (2000a) Cereal production and processing. In: Nicholson P, Shaw I (eds) Ancient Egyptian materials and technology. Cambridge University Press, Cambridge, pp 505-536

Murray MA (2000b) Fruits, vegetables, pulses and condiments. In: Nicholson P, Shaw I (eds) Ancient Egyptian materials and technology. Cambridge University Press, Cambridge, pp 609-655

Muthukumaran S (2016) Tree cotton (G. arboreum) in Babylonia. In: Foietta E, Ferrandi C, Quirico E et al (eds) Cultural and material contacts in the ancient near east. Proceedings of the international workshop 1-2 December 2014, Torino. Apice libri, Sesto Fiorentino, pp. 98-105

Nehmé L (ed) (2015) Les tombeaux nabatéens de Hégra. Académie des Inscriptions et Belles-lettres, Paris

Nehmé L, Al-Talhi D, Villeneuve F (eds.) (2011) Report on the fourth excavation season (2011) of the Madâ'in Sâlih archaeological project

Nehmé L, Arnoux T, Bessac JC et al (2006) Mission archéologique de Madâ'in Sâlih, Arabie Saoudite: Recherches menées de 2001 à 2003 dans l'ancienne Hijrâ des Nabatéens. Arab Archaeol Epigr 17:41-124

Newman RJ (1932) The agricultural life of the Jews in Babylonia between the years 200 C.E. and 500 C.E. Oxford University Press, London

Newton C, Whitbread T, Agut-Labordère D et al (2013) L'agriculture oasienne à l'époque perse dans le sud de l'oasis de Kharga (Égypte, Ve-IVe s. AEC), Revue d'ethnoécologie (4)

https://ethnoecologie.revues.org/1294. Accessed 26 May 2017

Nicholson GE (1960) The production, history, uses and relationships of cotton (Gossypium spp.) in Ethiopia. Econ Bot 14(1):3-36

Obeid M, Mahmoud A (1971) Ecological studies in the vegetation of the Sudan. II. The ecological relationships of the vegetation of Khartoum province. Vegetatio 23(3-4):177-198

Omer SA, Agab H, Samad HA et al (2008) Effect of feed type on some blood constituents of Sudanese growing camel (Camelus dromedarius) calves. Sud J Vet Sci Anim Husb 47 (2):107-116

Page JT, Huynh MD, Liechty ZS et al (2013) Insights into the evolution of cotton diploids and polyploids from whole-genome re-sequencing. G3: Genes Genom Genet 3(10):1809-1818 
Palmer SA, Clapham AJ, Rose P et al (2012) Archaeogenomic evidence of punctuated genome evolution in Gossypium. Mol Biol Evol 29(8):2031-2038

Palmer SA, Moore JD, Clapham AJ et al (2009) Archaeogenetic evidence of ancient Nubian barley evolution from six to two-row indicates local adaptation. PLoS ONE 4(7):e6301

Paterson AH, Wendel JF, Gundlach H et al (2012) Repeated polyploidization of Gossypium genomes and the evolution of spinnable cotton fibres. Nature 492(7429):423-427

Pelling R (2013) The archaeobotanical remains (Chap. 18) and Botanical data appendices (Chap. 28), in The Archaeology of Fazzan, vol. 4. In: Mattingly DJ, Daniels CM, Dore JN et al. (eds) Survey and excavations at old jarma (Ancient Garama) carried out by C.M. Daniels (1961-1969) and the fazzan project (1997-2001). Society of Lybian Studies, Department of Antiquities, Londres, 473-94:841-852

Phillipson DW (ed) (2000) Archaeology of Axum, Ethiopia, 1993-1997, vol II. The Society of Antiquaries, London

Phillipson DW (2012) Foundations of an African civilisation. Aksum and the Northern Horn 1000 BC-AD 1300 (Eastern Africa Series). Boydell \& Brewer, New York

Plumley JM, Adams WY, Crowfoot E (1977) Qasr Ibrim 1976. J Egypt Archaeol 63:29-47

Rahmani LY (1967) Jason's tomb. Israel Exploration Soc 17(2):61-100

Reimer PJ, Bard E, Bayliss A et al (2013) IntCal13 and Marine13 radiocarbon age calibration curves 0-50,000 years cal BP. Radiocarbon 55(4):1869-1887

Reis D, Vian B, Bajon C (2006) Le Monde Des fibres. Belin, Paris

Riello G, Roy T (2009) How India clothed the world. The world of South Asian textiles, 1500 1850 (Global Economic History Series). Brill, Leiden

Rilly C (2007) La Langue Du Royaume de Méroé: Un Panorama de La plus Ancienne Culture Écrite d'Afrique Subsaharienne. H. Champion, Paris

Rose P (1996) Qasr Ibrim: the Hinterland survey. Egypt Exploration Society, Cairo

Rose P (2013) Qasr Ibrim: the encyclopedia of ancient history. Wiley, Chichester

Rose PJ (2011) Kirwan memorial lecture. Qasr Ibrim: The last 3000 years. Sudan Nubia 15:3-12

Rose PJ, Edwards DN (1998) Excavations at Qasr Ibrim. Sudan Nubia 2:61-73

Rowley-Conwy P (1989) Nubia AD 0-550 and the 'Islamic'agricultural revolution: preliminary botanical evidence from Qasr Ibrim, Egyptian Nubia. Archéologie du Nil Moyen 3:131-138

Rowley-Conwy PA, Deakin W, Shaw CH (1999) Ancient DNA from Sorghum. The evidence from Qasr Ibrim, Egyptian Nubia. In: Van der Veen M (ed) The exploitation of plant resources in ancient Africa. Kluwer Academic, New York, pp 55-61

Ryesky D (1984) The textiles. In: Wenke RJ (ed) Archaeological investigations at El-Hibeh 1980: preliminary report. Undena, Malibu, pp 78-93

Samuel D (2001) Archaeobotanical evidence and analysis. In: Berthier S (ed) Peuplement Rural et Amenagements Hydroagricoles Dans La Moyenne Vallee de l'Euphrate Fin VIIe-XIXe Siecle. Institut français d'études arabes de Damas, Damascus, pp 343-481

Sanlaville P (2000) Le Moyen-Orient Arabe: Le Milieu et L'homme. Nathan, Paris

Schmidt-Colinet A (1995) Palmyra: Kulturbegegnung Im Grenzbereich. Verlag Philipp von Zabern, Mainz am Rhein

Shamir O (2015) Egyptian and Nubian textiles from Qasr el-Yahud, 9th century AD. In: De Moor A, Fluck C, Linscheid P (eds) Tielt: textiles, tools and techniques of the 1st Millenium AD from Egypt and neighbouring countries. proceedings of the 8th conference of the research group 'Textiles from the Nile Valley'. Antwerp, 4-6 October 2013, Lannoo

Shamir O, Baginski A (2013) Textile hoard from Jericho Cave 38 in the Qarantal Cliff. In: Guri-Rimon $\mathrm{O}$ (ed) Hoards and genizot as chapters in history. Hecht Museum University of Haifa, Haifa, pp 77-88 
Shamir O, Baginski A (2014) The earliest cotton Ikat textiles from Nahal'Omer Israel 650-810 CE. In: Nosch M-L, Feng Z, Varadarajan L (eds) Global textile encounters (Ancient textiles series 20). Oxbow books, Oxford, pp 65-73

Shaw CH, Deakin WJ, Rowley-Conwy PA (2001) Ancient DNA from archaeological Sorghum from Qasr Ibrim, Egyptian Nubia. In: Millard A (ed) archaeological sciences'97 proceedings of the conference held at the University of Durham, 2nd-4th September 1997 (BAR International Series). Oxbow Books, Oxford, p. 96-99

Sheffer A, Tidhar A (1991) The textiles from the 'En-Boqeq excavation in Israel. Text Hist 22 (1):3-46

Sherratt A (1999) Cash-crops before cash: organic consumables and trade. In: Gosden C, Hather J (eds) The prehistory of food: appetites for change. Routledge, London, pp 13-34

Smith CE, Stephens SG (1971) Critical identification of Mexican archaeological cotton remains. Econ Bot 25(2):160-168

Smith CW, Cothren TJ (1999) Cotton: origin, history technology and production. Wiley, New York

Smith O, Clapham AJ, Rose P et al (2014) Genomic methylation patterns in archaeological barley show de-methylation as a time-dependent diagenetic process. Sci Report 4

Stanton MA, Stewart JM, Pervical AE et al (1994) Morphological diversity and relationships in the A-Genome Cottons, Gossypium arboreum and G. herbaceum. Crop Sci 34(2):519

Stauffer A (2000) The textiles from Palmyra: technical analyses and their evidence for archaeological research. In: Cardon D, Feugère M (eds) Archéologie Des Textiles, Des Origines Au Ve Siècle: Actes Du Colloque de Lattes, Octobre 1999. Monique Mergoil, Montagnac, pp 247-252

Stephens SG (1975) A reexamination of the cotton remains from Huaca Prieta. North Coastal Peru. Am Antiquity 40(4):406-419

Stephens SG (1976) Some observations on photoperiodism and the development of annual forms of domesticated cottons. Econ Bot 30(4):409-418

Strouhal E (1984) Wadi Qitna and Kalabsha South I: archaeology. Czech Institute of Egyptology, Prague

Suttie JM (2004) Conservation Du Foin et de La Paille Pour Les Petits Paysans et Les Pasteurs (Collection FAO, production végétale et protection des plantes 29). Organisation des Nations Unies pour l'alimentation et l'agriculture, Roma

Tallet G, Gradel C, Letellier-Willemin F (2012) 'Une laine bien plus belle et douce que celle des moutons' à El-Deir (oasis de Kharga, Égypte): le coton au cœur de l'économie oasienne à l'époque romaine. In: Guédon S (ed) Entre Afrique et Égypte: Relations et Échanges Entre Les Espaces Du Sud de La Méditerranée À L'époque Romaine. Ausonius, Bordeaux, pp 119141

Tengberg M, Lombard P (2001) Environnement et économie végétale à Qal'at al-Bahreïn aux périodes Dilmoun et Tylos. Premiers éléments d'archéobotanique. Paléorient 27(1):167-181

Tengberg M, Newton C (2016) Origine et évolution de la phéniciculture au Moyen-Orient et en Égypte. In: Ruas MP (ed) Des Fruits D'ici et D'ailleurs: regards Sur L'histoire de Quelques Fruits Consommés En Europe. Omnisciences, Paris, pp 83-105

Terpstra T (2015) Roman trade with the Far East: Evidence for Nabataean middlemen in Puteoli. In: De Romanis F, Maiuro M (eds) Across the Ocean: nine essays on Indo-Mediterranean trade (Columbia Studies in the Classical Tradition). Brill, Leiden, pp 73-94

Thanheiser U (2002) Roman agriculture and gardening in Egypt as seen from Kellis. In: Hope CA, Bowen GE (eds) Dakhleh Oasis project: preliminary reports on the 1994-1995 to 1998-1999 Field Seasons. Oxbow Books, Oxford, pp 299-310 
Thanheiser U, Kahlheber S, Dupras T (2016) Pearl millet, Pennisetum glaucum (L.) R.Br. ssp. glaucum, in the Dakhleh Oasis, Egypt. In: Thanheiser U (ed) News from the past: progress in African archaeobotany. Proceedings of the 7th international workshop on African archaeobotany in Vienna, 2-5 July 2012 (Advances in Archaeobotany 3). Barkhuis, Groningen, pp. 115-125

Thanheiser U, Walter J (2015) Plant use in a Romano-Egyptian household in the third century CE. In: Boozer AL (ed) Amheida II: a late Romano-Egyptian house in the Dakhleh Oasis. Amheida House B2. The Institute for the study of the Ancient world, New York, pp. 375-392

Thurston TL, Fisher CT (2007) An introduction to the archaeology of subsistence intensification, innovation, and change. In: Thurston TL, Fisher CT (eds) Seeking a richer harvest (Studies in Human Ecology and Adaptation 3). Springer, New York, pp 1-23

Török L (1988) Late antique nubia, history and archaeology of the Southern Neighbor of Egypt in the 4th-6th C. AD (Antaeus 16). Archaeological Institute of the Hungarian Academy of Sciences, Budapest

Trolinder EL (2009) Genetic engineering of cotton. In: Paterson AH (ed) Genetics and genomics of cotton (Plant Genetics and Genomics: Crops and Models 3). Springer, New York, pp 187207

Van der Veen M (1999) The economic value of chaff and straw in arid and temperate zones. Veg Hist Archaeobot 8(3):211-224

Van der Veen M (2007) Formation processes of desiccated and carbonized plant remains - the identification of routine practice. J Archaeol Sci 34(6):968-990

Van der Veen M (2011) Consumption, trade and innovation: exploring the botanical remains from the Roman and Islamic ports at Quseir Al-Qadim. Africa Magna Verlag, Frankfurt, Egypt

Varisco D (2009) Agriculture in al-Hamdānī's Yemen: a survey from early Islamic geographical texts. J Econ Social Hist Orient 52:382-412

Vila A (1967) Aksha II Le cimetière méroïtique d'Aksha. Librairie Klincksieck, Paris

Vogelsang-Eastwood G (2001) Textiles. In: Grzymski KA, Anderson J (eds) Hambukol excavations, 1986-1989. Benben, Mississauga, pp 79-83

Vollesen K (1987) The native species of Gossypium (Malvaceae) in Africa, Arabia and Pakistan. Kew Bull 42(2):337-349

Wagner G (1987) Les Oasis d'Égypte, à l'époque grecque, romaine et byzantine d'après les documents grecs (BiEtud 100). Institut Français d'Archéologie Orientale, Cairo

Wagner G (1999) Les Ostraca Grecs de Douch IV (Document de fouille de l'Institut français d'archéologie orientale 24). Institut Français d'Archéologie Orientale, Cairo

Wagner G (2001) Les Ostraca grecs de Douch V (Document de fouille de l'Institut français d'archéologie orientale 24). Institut Français d'Archéologie Orientale, Cairo

Walsh RPD (1991) Climate, hydrology, and water resources. In: Craig GM (ed.) Agriculture in the Sudan. Oxford University Press, Oxford

Walshaw SC (2010) Converting to rice: urbanization, Islamization and crops on Pemba Island, Tanzania, AD 700-1500. World Archaeol 42(1):137-154

Watson AM (1983) Agricultural innovation in the early Islamic world: the diffusion of crops and farming techniques, 700-1100. Cambridge University Press, Cambridge

Wendel JF, Brubaker C, Alvarez I et al (2009) Evolution and natural history of the cotton genus. In: Paterson AH (ed) Genetics and genomics of cotton (Plant Genetics and Genomics: Crops and Models 3). Springer, New York, pp 3-22

Wendel JF, Cronn RC (2003) Polyploidy and the evolutionary history of cotton. Adv Agron 78:139-186 
Wendel JF, Small RL, Cronn RC et al (1999) Genes, jeans, and genomes: reconstructing the history of cotton. In: Proceedings of the International Organization of Plant Biosystematists, Amsterdam, pp. 133-161

Whitewright J (2007) Roman rigging material from the Red Sea port of Myos Hormos. Int J Naut Archaeol 36(2):282-292

Wild FC, Wild JP (2001) Sails from the Roman port at Berenike. Egypt. Int J Naut Archaeol 30 (2):211-220

Wild JP (1997) Cotton in Roman Egypt: some problems of origin. Al-Rafidan 18:287-298

Wild JP (2013) The first Indian carpets - a view from Berenike. In: De Moor A, Fluck C (eds) Drawing the threads together: proceedings of the 7th conference of the research group 'Textiles from the Nile Valley', Antwerp, 7-9 October 2009. Lannoo, Tielt, pp. 74-85

Wild JP, Wild FC (2008) Cotton: the new wool. Qasr Ibrim study season 2008. Archaeol Text Newsl 46:23-26

Wild JP, Wild FC (2009) Qasr Ibrim study: study season 2009(49):16-18

Wild JP, Wild FC (2014a) Through Roman eyes: cotton textiles from Early Historic India. In: Bergerbrant S, Fossøy SH (eds) A stitch in time. Essays in Honour of Lise Bender Jørgensen (Gothenburg Archaeological studies 4). Gothenburg University, Gothenburg, pp. 209-235

Wild JP, Wild FC (2014b) Qasr Ibrim: new perspectives on the changing textile cultures of Lower Nubia. In: Egypt in ER O'Connell (ed) the First Millenium A.D. (British Museum Publications on Egypt and Sudan 2). Peeters Publishers, Louvain, pp. 71-80

Wild JP, Wild FC (2014c) Berenike and textile trade on the Indian ocean. In: Droß-Krüpe K (ed) Textile trade and distribution in antiquity. Harrassowitz, Wiesbaden, pp 91-110

Wild JP, Wild FC, Clapham AJ (2007) Irrigation and the spread of cotton growing in Roman times. Archaeol Text Newsl 44:16-18

Wilkinson TC (2014) Tying the threads of Eurasia. Trans-regional routes and material flows in Transcaucasia, Eastern Anatolia and Western Central Asia, c. 3000-1500 BC. Sidestone Press, Leiden

Wilson LM (1933) Ancient textiles from Egypt in the university of michigan collection. University of Michigan Press, Ann Arbor

Winter JG, Youtie HC (1944) Cotton in graeco Roman Egypt. Am J Philology 65:249-258

Worp KA (1995) Greek Papyri from Kellis I (Dakhleh Oasis Project 3). Oxbow Monograph, Oxford

Worp KA, Hope CA (2004) Greek Ostraka from Kellis: O. Oxbow Books, Oxford, Kellis

Wulff HE (1966) The traditional crafts of Persia: their development, technology, and influence on Eastern and Western civilizations. M.I.T Press, Cambridge

Yvanez E (2012) Les textiles des nécropoles méroïtiques de Saï. Cahiers de recherches de l'Institut de papyrologie et d'égyptologie de Lille 29:331-344

Yvanez E (2015) De fil en aiguille: aspects de l'artisanat textile méroïtique. Egypte Afrique et Orient 78:63-66

Yvanez E (2016) Spinning in Meroitic Sudan: textile production implements from Abu Geili. Dotawo: J Nubian Stud 3:153-178

Zech-Matterne V, Tengberg M, Andringa VW (2015) Sesamum indicum L. (sesame) in 2nd century BC Pompeii, southwest Italy, and a review of early sesame finds in Asia and Europe. Veg Hist Archaeobot 24(6):673-81 


\section{Author Query Form}

Book ID : 416740_1_En

Chapter No : 18

\section{䈂 Springer}

the language of science

Please ensure you fill out your response to the queries raised below and return this form along with your corrections.

Dear Author,

During the process of typesetting your chapter, the following queries have arisen. Please check your typeset proof carefully against the queries listed below and mark the necessary changes either directly on the proof/online grid or in the 'Author's response' area provided below

\begin{tabular}{|l|l|l|}
\hline Query Refs. & Details Required & Author's Response \\
\hline AQ1 & Please provide complete affiliation details “Organisation name” for Aff2. & \\
\hline
\end{tabular}




\section{Please correct and return this set}

Please use the proof correction marks shown below for all alterations and corrections. If you wish to return your proof by fax you should ensure that all amendments are written clearly in dark ink and are made well within the page margins.

\begin{tabular}{|c|c|c|}
\hline Instruction to printer & Textual mark & Marginal mark \\
\hline Leave unchanged & $\cdots$ under matter to remain & ( \\
\hline $\begin{array}{l}\text { Insert in text the matter } \\
\text { indicated in the margin }\end{array}$ & $\Lambda$ & $\begin{array}{l}\text { New matter followed by } \\
h \text { or } h \otimes\end{array}$ \\
\hline Delete & $\begin{array}{l}\text { I through single character, rule or underline } \\
\text { or }\end{array}$ & $\sigma$ or $\sigma / \otimes$ \\
\hline $\begin{array}{l}\text { Substitute character or } \\
\text { substitute part of one or } \\
\text { more word(s) }\end{array}$ & / through letter or & $\begin{array}{l}\text { new character / or } \\
\text { new characters / }\end{array}$ \\
\hline Change to italics & — under matter to be changed & $\leftarrow$ \\
\hline Change to capitals & $\equiv$ under matter to be changed & $\equiv$ \\
\hline Change to small capitals & $=$ under matter to be changed & $=$ \\
\hline Change to bold type & $\sim$ under matter to be changed & $\sim$ \\
\hline Change to bold italic & $\approx \sim$ under matter to be changed & $\widehat{\omega n}$ \\
\hline Change to lower case & Encircle matter to be changed & $\not$ \\
\hline Change italic to upright type & (As above) & \\
\hline Change bold to non-bold type & (As above) & nqu \\
\hline Insert 'superior' character & $\begin{array}{l}\text { I through character or } \\
K \text { where required }\end{array}$ & $\begin{array}{l}y^{\prime} \text { or } y \\
\text { under character } \\
\text { e.g. } y^{2} \text { or } y^{2}\end{array}$ \\
\hline Insert 'inferior' character & (As above) & $\begin{array}{l}\text { L } \\
\text { over character } \\
\text { e.g. } \hat{\imath}\end{array}$ \\
\hline Insert full stop & (As above) & $\odot$ \\
\hline Insert comma & (As above) & , \\
\hline Insert single quotation marks & (As above) & $\begin{array}{l}\dot{y} \text { or } \dot{X} \text { and/or } \\
\dot{y} \text { or } \dot{y}\end{array}$ \\
\hline Insert double quotation marks & (As above) & $\begin{array}{l}\dddot{y} \text { or } \ddot{x} \text { and/or } \\
\ddot{y} \text { or } \ddot{x}\end{array}$ \\
\hline Insert hyphen & (As above) & $1-1$ \\
\hline Start new paragraph & $\digamma$ & 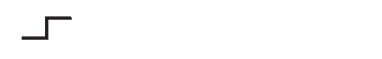 \\
\hline No new paragraph & 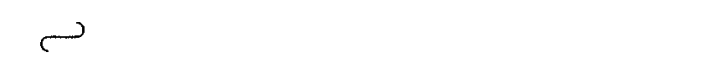 & 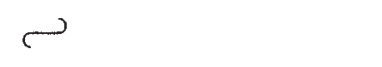 \\
\hline Transpose & $\sqcup$ & ᄃ \\
\hline Close up & linking $\bigcirc$ characters & \\
\hline $\begin{array}{l}\text { Insert or substitute space } \\
\text { between characters or words }\end{array}$ & $\begin{array}{l}\text { I through character or } \\
\Lambda \text { where required }\end{array}$ & \\
\hline $\begin{array}{l}\text { Reduce space between } \\
\text { characters or words }\end{array}$ & $\begin{array}{l}\text { between characters or } \\
\text { words affected }\end{array}$ & $\uparrow$ \\
\hline
\end{tabular}

